Contemporary Social Science

Journal of the Academy of Social Sciences

ISSN: 2158-2041 (Print) 2158-205X (Online) Journal homepage: http://www.tandfonline.com/loi/rsoc21

\title{
A new international measure of social stratification
}

\section{Cinzia Meraviglia, Harry B.G. Ganzeboom \& Deborah De Luca}

To cite this article: Cinzia Meraviglia, Harry B.G. Ganzeboom \& Deborah De Luca (2016): A new international measure of social stratification, Contemporary Social Science, DOI: 10.1080/21582041.2016.1215512

To link to this article: http://dx.doi.org/10.1080/21582041.2016.1215512

$$
\text { Published online: } 18 \text { Aug } 2016 .
$$

Submit your article to this journal $₫$

Q View related articles $\square$

View Crossmark data ¿ 


\title{
A new international measure of social stratification
}

\author{
Cinzia Meraviglia $^{\mathrm{a} *}$ (D), Harry B.G. Ganzeboom ${ }^{\mathrm{b}}$ and Deborah De Luca ${ }^{\mathrm{a}}$ \\ ${ }^{a}$ Department of Social and Political Sciences, University of Milan, Milan, Italy, ${ }^{b}$ Department of Sociology, \\ Free University Amsterdam, Amsterdam, The Netherlands
}

(Received 4 November 2015; accepted 18 July 2016)

\begin{abstract}
In this paper we present a new international measure of social stratification, the ICAMS (International Cambridge Scale). Our aim is to bring new evidence to the hypothesis that the construct that underlies measures of social stratification as different as prestige scales, socioeconomic indexes, social distance and social status scales is actually unidimensional. We evaluate the new scale according to both criterion-related and construct validity. Our analysis shows that the ICAMS is a valid indicator of social stratification, being almost as valid as International Socio-Economic Index (ISEI) in what we termed the generic, the homogamy and the social mobility models, and being better than ISEI in the cultural consumption model. The second key result is that all continuous measures we consider (ICAMS, ISEI and Standard International Occupational Prestige Scale) are indicators of the same latent dimension, which is unidimensional. This latter result is compatible with more than one explanation, hence calling for further research.
\end{abstract}

Keywords: social status; socio-economic status; prestige; social distance; occupational status

\section{Introduction}

Almost a century separates the very first attempts to build a continuous measure of social stratification based on occupation (Counts, 1925; Coutu, 1936) from the more recent measures (Chan, 2010; Chan \& Goldthorpe, 2004; De Luca, Meraviglia, \& Ganzeboom, 2012). ${ }^{1}$ In this time span, the concepts of occupational prestige, socio-economic status and social distance have come to identify three different traditions of social stratification research, each with its supporters. Whether these dimensions are truly different, or they are different specifications of the same underlying construct, is an issue that raised the attention of social stratification scholars as early as the mid-1940s (see e.g. Merton, 1949).

In this paper we present a new international measure of social stratification, the ICAMS (International Cambridge Scale). Our aim is not to increase the already substantial complexity of the field (effectively portrayed by Lambert \& Bihagen, 2012), but instead to reduce it: while validating the new scale as a measure of social stratification, we will show that the construct that underlies measures as different as prestige scales, socio-economic indexes (SEIs) and social distance scales is unidimensional, thus reinforcing the conclusions arrived at previously by other authors (see e.g. De Luca et al., 2012; Featherman \& Hauser, 1976; Featherman, Jones, \& Hauser, 1975; Kahl \& Davis, 1955; Kraus, Schild, \& Hodge, 1978; Stevens \& Featherman, 1981).

*Corresponding author. Email: cinzia.meraviglia@unimi.it 
Our aim is not merely empirical, though. By reviewing the relevant literature we show that, by the time the first stratification measures were produced in the 1920s, many relationships existed between the key concepts which today we consider as entirely distinct from one another. We thus intend to bring into light the main lines of development of stratification research in respect to our central question, namely whether social stratification is the single and unique dimension underlying all empirical continuous measures, or rather is a multi-dimensional structure which should be studied using the distinct concepts of social status, prestige, socio-economic status and social distance.

\section{The building of social stratification measures: from status to prestige, and back to status}

The earliest attempts to build an empirical measure of social stratification were based on social status. $^{2}$ Counts (1925) was the first who built a 'prestige or status scale', as Smith (1943, p. 185) describes it; in the next 20 years, 12 scholars followed Count's example. ${ }^{3}$ The dominant empirical mode of this period was that of community studies (Coleman, 1986); the samples of both occupations and respondents were rather small; ${ }^{4}$ interviews were often conducted without a questionnaire; direct observation of the setting of study was also common. From an empirical standpoint, the results attained by these studies 'stubbornly resist generalization, so rooted are they in local idiosyncrasy' (Hatt, 1950, p. 535); this feature prevented them from becoming a model for studies on a larger, nation-wide scale. From a theoretical standpoint, they are characterised by a high fluidity between the core concepts - a fluidity that presently sounds rather odd: an empirical stratification measure could be said to measure status or prestige (Smith, 1943); status hierarchies were seen as based upon prestige (Hollingshead, 1948; Warner, Meeker, \& Eells, 1949; Wheeler, 1949); classes were thought to be prestige communities (MacIver \& Page, 1949; Williams, 1951), or status groups (Gordon, 1951), while an occupational scale could serve as an index of social class (Blishen, 1958).

While noting that 'probably no area of sociological interest suffers so much from the disease of overconceptualization', Pfautz (1953, p. 392) recalls the impressive array of terms used in stratification research, listed by Merton; ${ }^{5}$ as for how to overcome this disorganised multiplication, Merton (1949/1968) himself invites the researchers to investigate whether the various concepts refer to different dimensions of stratification, and to find out the interrelations among them.

His advice influenced the work of many scholars after the 1940s, when the dominant mode of empirical research turned into survey research (Coleman, 1986). This second period - which lasts until our days - presents some distinctive features. First and most notably, occupation becomes the key indicator of social position. If this comes as a natural choice in the framework of functionalist sociology (see e.g. Parsons, 1940), practical reasons also played a role, given either the relative availability of empirical data on occupation, or the relative easiness of collecting such information in large-scale surveys. ${ }^{6}$

The choice of occupation as the key indicator of social position is accompanied by a conceptual shift: while the early empirical attempts to build continuous measures of social position were based on social status, from the 1940s on the attention goes to prestige. As a consequence, occupational stratification (which follows from the concept of occupational prestige) is preferred over social stratification (which is inherent in the concept of social status).

A second feature of this period is that empirical research was conducted on a much larger scale than previously (see e.g. Smith, 1943). The National Opinion Research Center (NORC) scale is the first study to be truly representative of the modern style of research (North \& Hatt, 1947). Its importance also lies in the use that Duncan (1961) made of it. As is well known, Duncan built his SEI in order to overcome a major limitation of the NORC scale, namely that the occupations rated 
concerned less than half of the US labour force. Duncan's SEI 'was developed and accepted in large part because, for the first time, it provided an index of the status of all U.S. occupations' (Hauser \& Logan, 1992, p. 1692). On a conceptual level, in Duncan's perspective prestige is the concept underlying both the NORC scale and the SEI. However, some years later Featherman et al. (1975) and Featherman and Hauser (1976) invert the concept-indicator relationship, claiming that "prestige scores are "error-prone" estimates of the socioeconomic attributes of occupations' (Featherman \& Hauser, 1976, p. 405), and that 'whatever it is that prestige scores scale ... it is substantively different from socioeconomic status' (Featherman \& Hauser, 1976).

The last approach to continuous measurement of social stratification we review is that of social distance scales. It was initiated by Laumann $(1965,1966,1973)$ and Laumann and Guttman (1966), who argue that the existence of classes can be inferred starting from how people cluster in everyday life. In this perspective, class is not the Weberian grouping of individuals according to their market situation, since it is conceptualised as the confluence of the economic and symbolic dimensions: a class is also a status group in the Weberian sense, capable of expressing itself (also) through connubium and commensality (Weber, 1922/1978, p. 306), ${ }^{7}$ or through 'associational propensities' (Laumann \& Guttman, 1966, p. 170).

This conceptualisation has been adopted by two research streams. The first one is that of the Cambridge group, who built the Cambridge Social Interaction and Stratification Scale (CAMSIS) (Prandy, 1990; Prandy and Lambert, 2003; Stewart, Prandy, \& Blackburn, 1973, 1980; for a North American example see Rytina, 1992). The Cambridge group considers the social structure as emerging from the association among a given set of occupations as a stratification order in itself, which cannot be reduced to any of the existing and already explored constructs (prestige or socio-economic status) (Bottero \& Prandy, 2003). This emerging social structure has a cultural as well as an economic character, thus obliterating the concept of social class as distinct from that of social status, and merging the two concepts into that of social distance (Bottero \& Prandy, 2003).

Following the example of the Cambridge group, recently De Luca et al. (2012) developed a social distance measure for Italy (the CAMSIS-IT) and validated it by comparing the new scale to the International Socio-Economic Index (ISEI; Ganzeboom \& Treiman, 1996), the Standard International Occupational Prestige Scale (SIOPS; Treiman, 1977) and the Italian prestige scale (SIDES05; Meraviglia, 2012a) in the framework of a status attainment model. A key finding these authors arrived at is that 'there is no indication of a part of intergenerational status transfer that is unique to one or the other measure' (De Luca et al., 2012, p. 48).

The second approach is that of Chan and Goldthorpe (2004), who follow Laumann (1966; 1973 ) in building a status scale for Britain. Unlike the Cambridge group, these authors claim that the distinction between class and status is still useful for understanding contemporary society. They conduct several tests for supporting their claim with empirical evidence, either using friendship data (Chan and Goldthorpe 2005, 2007a, 2007b, 2007c), or marriage data, as in the case of Chan (2010), and Chan, Birkelund, Aas and Wiborg (2011), who also extend the domain of research to some European and American countries.

\section{Objectives}

The logical conclusion of almost a century of empirical enquiry would be that - notwithstanding the fact that the key concepts (prestige, social status, socio-economic status and social distance) have distinct theoretical roots - they are not distinct on the empirical level. Actually the conclusion which De Luca et al. (2012) arrived at is the last of a series of results confirming that the dimension implied by all gradational measures of social position is unitary (Featherman \& Hauser, 1976; Featherman et al., 1975; Griffiths \& Lambert, 2012; Kahl \& Davis, 1955; 
Stevens \& Featherman, 1981). Hence it might seem unnecessary to proceed further along the path of developing a new continuous measure of social stratification.

Our main rationale in doing so is that no international continuous measure based on either social distance or social status has been built yet. Actually two internationally valid measures of occupational stratification are available, namely the SIOPS (Treiman, 1977) and the ISEI (Ganzeboom \& Treiman, 1996). The SIOPS is the first international measure of occupational stratification to be produced, with the aim of fostering comparative research on occupational hierarchies. As its author notes (Treiman, 1977, p. 160), despite the fact that many prestige scales were available at that time, they were incomparable, either because they were built on partial and incomplete data, or because they followed similar but never identical procedures for estimating the prestige scores of given occupations. Treiman built the SIOPS by averaging the prestige scores of about 60 national prestige scales, and anchored these scores to the ISCO-68 occupational titles. He also showed that the SIOPS scores were closely correlated to the original 60 prestige scale scores, thus validating its measure for cross-country comparisons.

Some years later the ISEI followed the SIOPS (Ganzeboom, De Graaf, Treiman, \& De Leeuw, 1992), being however based on a different rationale. In fact, the ISEI extends to the international context the work done by Duncan (1961) on his SEI, at the same time giving SEI-like measures a new interpretation. As we saw, Duncan built the SEI in order to assign all occupations in the 1950 Census a prestige score, hence considering the SEI scores as proxy of the prestige scores, while Featherman et al. (1975) and Featherman and Hauser (1976) claimed that the latter were errorprone measures of the socio-economic dimension of occupations. In this vein, Ganzeboom and colleagues drop any reference to prestige and develop their new measure as the indicator of the process that translates educational credentials into income. In other terms, occupation can be seen as an intervening variable between education and income, transferring into the latter the knowledge, skills and abilities acquired through education. The authors use the data coming from the International Stratification and Mobility File (ISMF) (Ganzeboom \& Treiman, 1989), relative to gainfully employed males from 31 surveys in 16 countries (Ganzeboom \& Treiman, 1996), and validate their index against Treiman's SIOPS, showing that the two scales are similar, as expected of two measures referring to the same construct; however, they are far from identical, thus reinforcing the conclusion that 'prestige is better interpreted as a consequence of the dimensions used to construct occupational socio-economic status measures than as parallel to them' (Ganzeboom et al., 1992, p. 22).

In sum, the SIOPS and the ISEI are two (alternative) internationally valid measures of the hierarchical dimension of stratification, each referring to two different concepts, that is, prestige and socio-economic status. Comparative research has made wide use of both, with a preference for ISEI. However, no equivalent measure based on either social status or social distance has been made available yet. Such a measure is both interesting per se (e.g. as we will see, to study cultural consumption cross-nationally), and as a means to validate the hypothesis concerning the existence of a single dimension underlying all internationally valid measures of stratification. Concerning the latter goal, any test relying only on two measures (namely, SIOPS and ISEI) would not rule out the possibility for a status scale to represent a different dimension of stratification.

Besides reporting on the actual building of the new international measure, our aim is threefold. Firstly, we intend to show the properties of the ICAMS as a stratification measure; secondly, we intend to empirically test whether it is a valid measure of social stratification; thirdly, relying on the empirical test we will set out (multi-trait multi-method (MTMM) factor-analytic models), we want to assess whether the latent dimension underlying all available international measures (ICAMS, ISEI and SIOPS) is unique, hence producing fresh evidence on the dimensionality of the construct underpinning all gradational measures of social stratification. 


\section{Data and methods}

\subsection{Building the ICAMS}

The construction of the ICAMS followed the procedures described for building a CAMSIS scale, according to which a square table of occupational titles (either coming from husbands-wives couples, or from respondents-friends couples $)^{8}$ is used for estimating the scale scores. In our case, the latter were estimated using the data on spouses' occupation provided by six crosssection surveys of the International Social Survey Programme (ISSP) from 2001 to 2007. ${ }^{9}$

Not all ISSP countries conducted all the six surveys; hence some countries provide more data than others. Of the total number of cases in the 40 countries considered, we selected those with a valid ISCO-88 code for both the respondent's and his/her spouse's occupation, as found in the deposited data. We used the information provided by both female and male respondents who reported on own and his/her partner's occupation; more precisely, we assigned an occupation to the husbands' group whenever the respondent was male, or he was the spouse of a female respondent, and the same was done for female respondents or partners. This procedure resulted in 109,988 couples, each spouse being assigned to an ISCO-88 occupational title.

Despite this reasonably large sample size, the husbands $\times$ wives occupational table was very sparse; hence some under-represented occupational units were grouped to neighbouring ones, whenever this was acceptable from a substantive standpoint. ${ }^{10}$ This resulted in a $193 \times 193$ table of occupational titles, which was the input of the RC-II Goodman's association model (Goodman 1979; Clogg 1982; Hauser, 1984) through which the scale scores were estimated. ${ }^{11}$

Once a scale score for each detailed occupational title (or group of titles) in our $193 \times 193$ table was estimated, we assigned the same score to the occupational titles we previously grouped. In the case of occupational titles that were not present in the original ISSP data sets, we assigned them the score of a neighbouring and closely related title. ${ }^{12}$ This has been done for the sake of completeness, in order to provide a score for each and every occupational title in the ISCO-88. Following the same logic, we also estimated a set of three more association models on a $9 \times 9$ table (ISCO-88 major groups), a $26 \times 26$ table (sub-major groups) and a $115 \times 115$ table (minor groups), hence making the ICAMS usable even in those research instances in which a detailed four-digit ISCO- 88 code is not available. The complete list of ISCO-88 occupational titles and the associated ICAMS score are shown in Table A1 in the Appendix. ${ }^{13}$

\subsection{Validating the ICAMS}

Two main approaches are available for testing the validity of the new international measure, namely criterion-related validity and construct validity (Zeller \& Carmines, 1980). ${ }^{14}$ We evaluate the former by examining the correlations of the ICAMS with the available international measures of social stratification, that is, the ISEI and the SIOPS, while we test construct validity by means of a MTMM model (Saris \& Gallhofer, 2014).

The validation of the ICAMS requires a different data basis from the one used for its construction; ${ }^{15}$ for this purpose then we use rounds $1-5$ of the European Social Survey (ESS), which collects occupational information on respondent and his/her spouse, father and mother. ISCO-88 codes for respondent and spouse are provided by the national teams and are part of the main data. ${ }^{16}$ The ISCO-88 codes for fathers and mothers were recently produced by an ESS Developmental Project in the Netherlands and are publicly available from Ganzeboom (2014). Taken together, the ESS data cover over 250,000 respondents in 34 countries. We selected cases between 25 and 64 years of age (i.e. respondents in their prime working age), for which at least one occupation code was available, getting to a final sample of 163,760 observations. 
The three scales (ICAMS, ISEI and SIOPS) are gender-insensitive, in that they are applied indifferently to male and female data. ${ }^{17}$ In our validation exercise we wanted to empirically test their validity for the two genders separately; hence, we estimated our models on subsamples of female and male data.

All occupations in our analyses were given a three- or four-digit code of ISCO-88, which were translated into ICAMS, ISEI and SIOPS scores using routines made available by Harry B. G. Ganzeboom at http://www.harryganzeboom.nl/isco88/index.htm. For the estimation of the pooled cross-national structural equation models, the data were Z-standardised within countries. ${ }^{18}$

As for the modelling strategy, we analyse the behaviour of the ICAMS in the framework of a factor-analytic structural equation model, which contains four latent constructs (respondent's, spouse's, father's and mother's occupation). Other basic stratification variables are considered, in particular respondent's, spouse's, father's and mother's education, and the household income that respondents and spouses together produce and consume. It is important to note that in our models there are no causal relationships: the interest goes to how well the indicators connect to the latent variables, rather than to the causal structure that links the variables in the model.

The measuring of these indicators is straightforward. We use the three available continuous measures of social position, that is, ICAMS, ISEI and SIOPS, as indicators of each latent occupation, their scores being derived from the ISCO-88 code pertaining to each occupation. Education is measured by the potential duration of each (country-specific) qualification, ${ }^{19}$ which ranges from 0 (no formal education) to $23(\mathrm{PhD})$, while household income is routinely measured by the ESS by country-specific amounts, which we cross-nationally harmonised. ${ }^{20}$

The idea behind this model is that the behaviour of the various measures of social stratification (namely, ICAMS, ISEI and SIOPS) should not only be studied by looking at the correlations between them (as in criterion-related validity), but also in the context of a nomological network (Carmines \& Zeller, 1979; Cronbach \& Meehl, 1955), in which the occupational variables are considered in their meaningful relationship with other relevant variables (or, better, constructs) such as education and income.

If we consider our model in the perspective of MTMM models (Saris \& Andrews, 1991; Saris \& Gallhofer, 2014; Scherpenzeel \& Saris, 1997), the three continuous measures (ICAMS, ISEI and SIOPS) are methods that measure the same trait (the occupation of the four incumbents we consider). In Figure 1 we show the basic structure of this factor-analytic model; for the sake of clarity, Figure 1 portrays only two occupations (traits) and two indicators (methods); however, its representation can be easily generalised to $n$-traits and $m$-methods.

Assuming that each occupation has a 'true' score which reflects its positioning along the stratification continuum, the coefficients of our interest (namely, the factor loadings $a$ and $b$ in Figure 1) measure the degree to which each indicator reflects the 'true' position of an occupation (OCC1 in Figure 1) along the continuum of stratification. Given the specification of the model, the coefficients $a$ and $b$ also indicate the amount of information that the different measures share.

The coefficients $d$ and $e$ denote error terms, and represent the systematic variance that the indicators (i.e. the three scales) share across constructs (i.e. occupations). Our expectation is that these coefficients are irrelevant, since they can be interpreted either as systematic measurement error or bias, or - more problematically - as a sign of systematic deviation from the hypothesis of the three scales being indicators of the same underlying construct. ${ }^{21}$ We estimated all coefficients with structural equation modelling, for which we employed LISREL 8.8 .

Three different models belonging to the family we described were estimated. In what we called the generic model, all four occupations are used, that is, we have four latent constructs 


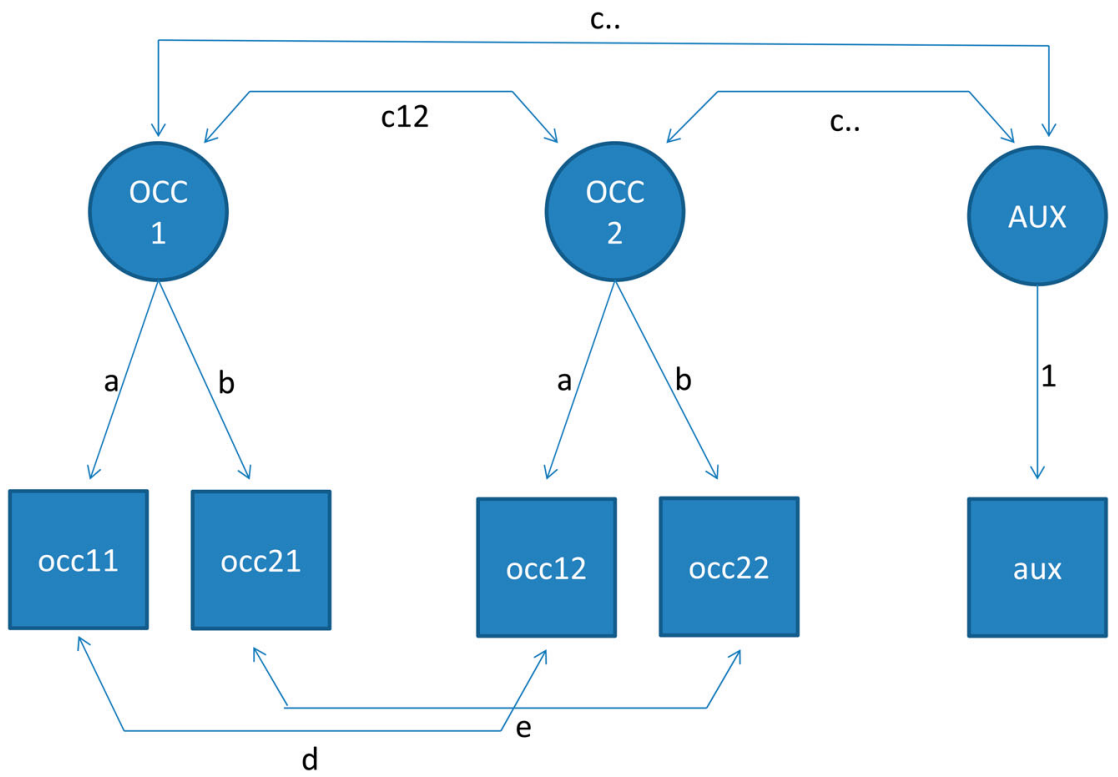

Figure 1. The MTMM validation model.

Note: OCC1, OCC2, Latent constructs; Occ11 ... occ22, observed indicators; AUX, aux, auxiliary variables.

referring to the occupations of the respondent's and his/her spouse's, father's and mother's; in the homogamy model, only the occupations of the respondent and his/her spouse are used, while in the social mobility model we concentrate on the relationship between both parents' occupation and respondent's occupation. This strategy is intended to evaluate construct validity on different grounds, in order to test the stability of our results.

As for fit measures, given the size of our sample (over 160,000 observations), our design is heavily overpowered, hence the usual model evaluation measures through significance testing make no sense. Nonetheless all our models fit the observed data with a Root Mean Square Error of Approximation (RMSEA) below 0.05, which means that the models reproduce fairly well the structure of our data.

Still in the attempt to test the validity of the new scale on many different grounds, we conduct a second validation exercise in the domain of social stratification and culture consumption. We follow Chan and Goldthorpe (2007a), who argued that social status is particularly relevant for the determination of status goods, such as the participation in high culture.

For this second exercise we used the 2007 ISSP module, thus breaching the rule that data used for the building of a scale should preferably not be used for its validation. However, ISSP 2007 provides a unique opportunity to test the Chan-Goldthorpe hypothesis in a large-scale, crossnational framework, since the ISSP 2007 year module was collected in 33 countries worldwide, ranging from Australia to the UK, Chile and Turkey.

After selection on the dependent variable (i.e. culture consumption), prime working age (2564 years) and the presence of a valid occupation code for respondent or spouse, we obtain a sample of 34,114 observations. Like in the ESS, occupations are coded with ISCO-88. We use both the occupation of respondent and his/her spouse, on the substantial argument that both are associated with culture consumption (which is very much a household activity). On an empirical standpoint, including spouse's occupation allows us to create a MTMM design, as we already did in our previous validation exercise. 
Table 1. The indicators of the cultural participation index.

\begin{tabular}{llrr}
\hline \multicolumn{1}{c}{ How often do you ... } & $\lambda$ & $\alpha$ \\
\hline V7 & Go to the movies & 0.705 & 0.519 \\
V9 & Read books & 0.616 & 0.554 \\
V10 & Attend cultural events such as concerts, live theatre and exhibitions & 0.695 & 0.513 \\
V14 & Listen to music & 0.396 & 0.626 \\
V18 & Spend time on the internet/PC & 0.665 & 0.532 \\
& Overall & & 0.605 \\
\hline
\end{tabular}

Note: Items standardised within countries using percentile scores. Original answers range between (1) Daily and (5) Never. $\lambda$ : component loading. $\alpha$ : Cronbach's reliability coefficient (if items deleted).

The ISSP 2007 module contains five indicators of cultural consumption (Table 1), which we summarised in an index. Book reading, going to the movies, attending cultural events and listening to music are obvious and frequently used indicators of culture consumption. To these we added the item on the internet/PC use, as another mode of information processing; it scales consistently with the previous four items and strengthens the reliability of the resulting index. The factor loadings and reliabilities (if item deleted) showed in Table 1 confirm the goodness of this choice. The overall reliability $(0.605)$ is not very high; however, this is not problematic, since it refers to the dependent variable - cultural consumption - in our MTMM model: in fact, random measurement error becomes part of the residual term of the equation and does not affect the relative size of the structural coefficients. Besides the occupation of the spouses, the variables in this model are the cultural participation index, logged household income and respondent's education. ${ }^{22}$

\section{Results}

The first step in the validation of the ICAMS concerns criterion validity, which we investigated by means of the correlations between the new measure and the existing ones, plus two additional criterion variables (respondent's education and his/her household income). For this task we use the ESS data.

As Table 2 (panel a) shows, ICAMS shows a closer correlation to ISEI than to SIOPS ( $r=.90$ and $r=.86$, respectively). Nonetheless both scales appear to be very closely related to ICAMS, with only two clearly identifiable outliers, namely group 1221 (production and operations department managers in agriculture, hunting, forestry and fishing) and group 1227 (production and operations department managers in business services). In both cases, ICAMS assigns to these groups a lower score than either ISEI or SIOPS, meaning that their status is lower when measured on a social status $\operatorname{scale}^{23}$ than when evaluated on either a prestige or a socio-economic scale.

The new scale also correlates very well with two additional criterion variables, namely respondent's education and household income; actually the correlation coefficient between ICAMS and years of education is the highest $(r=.60)$ among the three measures of stratification (for ISEI $r=.58$; for SIOPS, $r=.56$ ).

An interesting finding is that ICAMS shows higher correlations with the criterion variables in the non-manual range than in the manual one. As we see in Table 2 (panels b and c), the correlation between ICAMS and ISEI for non-manual occupations is 0.76 , while it is 0.63 for manual ones; likewise, the correlation between ICAMS and SIOPS drops from 0.77 for non-manual jobs to 0.43 for manual ones. The reason behind this finding can be found in the different standing of some occupational groups. Among the non-manual ones, nursing and midwifery associate 
Table 2. Pearson's correlation coefficients between respondent's ICAMS and the criterion variables (ESS rounds $1-5)$.

\begin{tabular}{lccccc}
\hline & ICAMS & ISEI & SIOPS & Years of education & (Log)Income \\
\hline (a) All occupations & & & & & \\
ICAMS & 1.00 & & & & \\
ISEI & 0.90 & 1.00 & & & \\
SIOPS & 0.86 & 0.88 & 1.00 & 1.00 & 1.00 \\
Years of education & 0.60 & 0.58 & 0.56 & 0.31 & \\
(Log)Income & 0.32 & 0.33 & 0.32 & & \\
(b) Non-manual occupations (ISCO-88 & Major Groups 1-4) & & \\
ICAMS & 1.00 & & & & \\
ISEI & 0.76 & 1.00 & & & \\
SIOPS & 0.77 & 0.82 & 1.00 & & \\
Years of education & 0.47 & 0.44 & 0.45 & & \\
(Log)Income & 0.16 & 0.20 & 0.20 & & \\
(c) Manual occupations (ISCO-88 Major Groups 5-9) & & & \\
ICAMS & 1.00 & & & & \\
ISEI & 0.63 & 1.00 & & & \\
SIOPS & 0.43 & 0.51 & 1.00 & 0.00 & \\
Years of education & 0.24 & 0.20 & 0.13 & & \\
(Log)Income & 0.12 & 0.14 & 0.12 & & \\
\hline
\end{tabular}

professionals and teaching associate professionals (respectively, groups 3200 and 3300 in the ISCO-88) enjoy a higher standing on the ICAMS than on the SIOPS or the ISEI. As a proof that these occupations are (at least partly) responsible for the poor correlation of the criterion variable with the ICAMS, we computed these correlations without groups 3200 and 3300; as we see in Table 3, the correlation coefficients get higher when computed leaving these two groups out.

The opposite is true in the case of some (relatively infrequent) occupations of ISCO- 88 group 6100 (charcoal burners, fishery workers, hunters and trappers), which score higher on the ISEI, a bit lower on the SIOPS and still lower on the ICAMS (with an average score of respectively 27.67, 22.47 and 18.64). In this case too we conducted a test by leaving out the occupational group we believe responsible for the low correlation between ICAMS and the criterion variables;

Table 3. Pearson's correlation coefficients between respondent's ICAMS and the criterion variables without some ISCO-88 occupational groups (ESS rounds 1-5).

\begin{tabular}{|c|c|c|c|c|c|}
\hline & ICAMS & ISEI & SIOPS & Years of education & (Log)Income \\
\hline \multicolumn{6}{|c|}{ (a) Non-manual occupations without groups 3200 and 3400} \\
\hline ICAMS & 1.00 & & & & \\
\hline ISEI & 0.79 & 1.00 & & & \\
\hline SIOPS & 0.81 & 0.84 & 1.00 & & \\
\hline Years of education & 0.50 & 0.48 & 0.48 & 1.00 & \\
\hline (Log)Income & 0.17 & 0.19 & 0.18 & 0.22 & 1.00 \\
\hline \multicolumn{6}{|c|}{ (b) Manual occupations without occupational units $6142,6152,6253,6154$} \\
\hline ICAMS & 1.00 & & & & \\
\hline ISEI & 0.63 & 1.00 & & & \\
\hline SIOPS & 0.47 & 0.50 & 1.00 & & \\
\hline Years of education & 0.28 & 0.20 & 0.13 & 1.00 & \\
\hline (Log)Income & 0.13 & 0.10 & 0.09 & 0.14 & 1.00 \\
\hline
\end{tabular}


panel $\mathrm{b}$ of Table 3 shows that some improvement is achieved by excluding four occupational units of ISCO-88 major group 6 (skilled agricultural and fishery workers).

Moving a step forward in the validation of our scale, we now turn to consider the results of the first MTMM design. Table 4 shows the estimated measurement coefficients for the two genders separately and together as for the generic model, the homogamy model and the social mobility model. ${ }^{24}$ The correlations between the latent variables with one another and the five auxiliary variables from the general model are also shown - just to convey the fact that these are strong validation criteria (see the Appendix, Table A2).

The results of all three models are highly consistent, showing that ICAMS is almost as valid a measure of the hierarchical dimension of stratification as ISEI. In the case of male data, ISEI is the most valid measure (factor loading of 0.96), followed by ICAMS (0.94) and SIOPS (0.92). In women's case, ISEI also scores better (0.96), while ICAMS and SIOPS are equally valid (factor loadings of, respectively, 0.94, 0.96 and 0.93/0.94).

These coefficients are very high and show that the three measures share a significant amount of information. Nevertheless, they also suggest that any correlation involving occupation would be attenuated by $4 \%$ (ISEI), 6\% (ICAMS) or 6-8\% (SIOPS in women's and men's case, respectively), should one prefer one indicator over another. ${ }^{25}$

Due to the large sample size and the constraints built into the model, the residual correlation for the method effects (coefficients $d$ and $e$ in Figure 1) are statistically significant, but - as expected - substantively negligible: both in the case of ICAMS and ISEI, they are always below 0.007 , and for SIOPS they are 0.013-0.015. These small numbers denote the systematic variance which is not reproduced by the model, hence indicating the unique variance component

Table 4. Parameters of the MTMM factor-analytic validation model on occupations (standardised coefficients, $t$-values and residual correlations) (ESS rounds $1-5$, men and women).

\begin{tabular}{|c|c|c|c|c|}
\hline & \multicolumn{2}{|c|}{ Men $N=75,939$} & \multicolumn{2}{|c|}{ Women $N=87,748$} \\
\hline & Measurement loading & Residual correlation & Measurement loading & Residual correlation \\
\hline \multicolumn{5}{|c|}{ Generic model } \\
\hline ICAMS & $\begin{array}{c}0.937 \\
(579.1)\end{array}$ & $\begin{array}{l}0.007 \\
(33.7)\end{array}$ & $\begin{array}{c}0.937 \\
(629.4)\end{array}$ & $\begin{array}{l}0.005 \\
(31.1)\end{array}$ \\
\hline ISEI & $\begin{array}{c}0.959 \\
(607.5)\end{array}$ & $\begin{array}{l}0.006 \\
(37.0)\end{array}$ & $\begin{array}{c}0.965 \\
(653.1)\end{array}$ & $\begin{array}{l}0.007 \\
(41.6)\end{array}$ \\
\hline SIOPS & $\begin{array}{c}0.913 \\
(549.8)\end{array}$ & $\begin{array}{l}0.015 \\
(63.4)\end{array}$ & $\begin{array}{c}0.929 \\
(603.2)\end{array}$ & $\begin{array}{l}0.013 \\
(61.7)\end{array}$ \\
\hline \multicolumn{5}{|c|}{ Homogamy model } \\
\hline ICAMS & $\begin{array}{c}0.946 \\
(432.8)\end{array}$ & $\begin{array}{l}0.006 \\
(13.2)\end{array}$ & $\begin{array}{c}0.940 \\
(470.8)\end{array}$ & $\begin{array}{l}0.008 \\
(21.0)\end{array}$ \\
\hline ISEI & $\begin{array}{c}0.961 \\
(451.0)\end{array}$ & $\begin{array}{l}0.007 \\
(17.3)\end{array}$ & $\begin{array}{c}0.964 \\
(480.9)\end{array}$ & $\begin{array}{l}0.006 \\
(16.9)\end{array}$ \\
\hline SIOPS & $\begin{array}{c}0.917 \\
(406.7)\end{array}$ & $\begin{array}{l}0.012 \\
(21.8)\end{array}$ & $\begin{array}{c}0.940 \\
(452.9)\end{array}$ & $\begin{array}{l}0.013 \\
(27.5)\end{array}$ \\
\hline \multicolumn{5}{|c|}{ Social mobility model } \\
\hline ICAMS & $\begin{array}{c}0.945 \\
(535.5)\end{array}$ & $\begin{array}{l}0.008 \\
(35.0)\end{array}$ & $\begin{array}{c}0.928 \\
(571.5)\end{array}$ & $\begin{array}{l}0.006 \\
(28.5)\end{array}$ \\
\hline ISEI & $\begin{array}{c}0.960 \\
(567.6)\end{array}$ & $\begin{array}{l}0.006 \\
(31.2)\end{array}$ & $\begin{array}{c}0.961 \\
(589.5)\end{array}$ & $\begin{array}{l}0.010 \\
(47.1)\end{array}$ \\
\hline SIOPS & $\begin{array}{c}0.901 \\
(504.4)\end{array}$ & $\begin{array}{l}0.019 \\
(63.5)\end{array}$ & $\begin{array}{c}0.935 \\
(552.9)\end{array}$ & $\begin{array}{l}0.015 \\
(55.2)\end{array}$ \\
\hline
\end{tabular}

Note: Auxiliary variables in the model: respondent's, spouse's, father's and mother's education, household income. All models fit the data with an RMSEA $<0.034$ or lower. 
Table 5. Parameters of the MTMM factor-analytic validation model on cultural consumption (standardised coefficients, $t$-values and residual correlations) (ISSP 2007, men and women).

\begin{tabular}{lccccc}
\hline & \multicolumn{2}{c}{ Men $N=15,368$} & & \multicolumn{2}{c}{ Women $N=18,741$} \\
\cline { 2 - 3 } \cline { 5 - 6 } & Measurement loading & Residual correlation & & Measurement loading & Residual correlation \\
\hline \multirow{2}{*}{ ICAMS } & 0.999 & 0.005 & & 0.990 & 0.000 \\
& $(172.8)$ & $(5.6)$ & & $(184.7)$ & $(0.1)$ \\
ISEI & 0.969 & 0.009 & & 0.941 & 0.018 \\
& $(186.6)$ & $(10.6)$ & & $(216.9)$ & $(22.7)$ \\
SIOPS & 0.907 & 0.120 & & 0.921 & 0.016 \\
& $(168.9)$ & $(13.8)$ & & $(158.8)$ & $(17.7)$ \\
\hline
\end{tabular}

Note: Auxiliary variables in the model: cultural participation index, respondent's education, household income. All models fit the data with RMSEA $<0.056$ or better.

which would point at the existence of other latent dimensions, apart from that identified by the model. Given their very small (though significant) value, this hypothesis is ruled out.

The second exercise in our validation strategy compares the three scales in the framework of a cultural consumption model. Table 5 shows the results of the MTMM model in which the scales are indicators of the underlying occupational status, as illustrated in Figure 1. Our results show that ICAMS is the most valid measure, when the explanation of cultural consumption behaviour is concerned: the factor loadings for ICAMS are 0.99, in case we consider the two genders either separately or together, while ISEI and SIOPS perform better, respectively, on male and female data. This points at the superiority of the new measure over the existing ones. As in previous models, residual correlations between each measure across occupations (which may mean that the three measures do not refer to the same latent construct) are negligible in size, especially in the case of ICAMS.

In sum, from a substantive standpoint we can say that, in relation to culture consumption, the effect of occupation is best captured by a social status measure like the ICAMS, which confirms the hypothesis formulated by Chan and Goldthorpe (2007a).

\section{Conclusion and discussion}

The building of continuous measures of social stratification is an exercise which started back in the 1920s. Since then, as we recalled, many measures have been built, leaving the stratification scholar with the puzzle of what exactly they measure (Lambert \& Bihagen, 2012), and whether they refer to the same underlying construct (Merton, 1949).

In this paper we intended to address the second issue. Our first step was the building of an international continuous measure of social stratification, the ICAMS, based on the work of Laumann and Guttman (1966) and on that of the Cambridge group (Bottero \& Prandy, 2003; Prandy, 1990). Such a measure, we believe, fills a gap in stratification research, which developed over the years an international measure of prestige (SIOPS; Treiman, 1977) and an international measure of socio-economic status (ISEI; Ganzeboom \& Treiman, 1996), while leaving the conceptual domain of social distance and social status without internationally valid measures.

Our second step consisted in the validation of the new measure. This step had multiple objectives. Firstly, we intended to show the properties of the ICAMS as a stratification measure; secondly, we wanted to empirically test whether it is a valid measure of social stratification; thirdly, relying on the empirical test we set out (MTMM factor-analytic models), we wanted to assess 
whether the latent dimension underlying all available continuous measures (ICAMS, ISEI and SIOPS) was unique.

The answers to these three questions are easily summarised. Firstly, we find that the ICAMS correlates very well with the criterion variables (Table 2, panel a), following the behaviour of the other two already-established international measures, namely ISEI and SIOPS. Secondly, as Tables 4 and 5 show, the ICAMS is a valid indicator of social stratification, being almost as valid as ISEI in what we termed the generic, the homogamy and the social mobility models, and being better than ISEI in the cultural consumption model. Lastly, as these same validation models suggest, there is no indication of multiple dimensions underlying the three measures or, otherwise said and despite the different conceptual underpinnings upon which the various scales rest, the latent construct implied by all of them is unidimensional.

We regard the latter result as particularly noteworthy. On one side, it confirms previous evidence attained by stratification scholars (see Section 2); on the other side, though, it leaves open the first of the two puzzle we mentioned earlier, namely that of what exactly all continuous measures measure.

Actually, the outcome concerning the uniqueness of the latent construct underlying all continuous measures of social position could have at least three meanings. First, on a conceptual level, it could point at the fact that the boundaries between the four conceptual areas, as we described them (prestige, social status, socio-economic status and social distance), are indeed rather blurry, just as they were at the beginning of the empirical endeavours to produce a continuous measure of social position (see Section 2). Second, however, and in line with other recent findings (e.g. Lambert \& Bihagen, 2012), it could also point at the weakness of the connection between the theoretical underpinnings and the empirical outcomes of the four research traditions in designing continuous measures of social stratification, since none of the measures we considered shows clear and strong connections with the theory which they are supposed to embody. As a third alternative explanation, all continuous measures of social position could highly correlate to one another because they have been built on the same piece of information, namely occupation, thus resulting in a methodological artefact.

In order to solve this puzzle, further research is needed. The first alternative explanation would imply that the vast body of empirical research produced good evidence that the relevant concepts are less sharply defined than expected. The burden then would be on theory, which should incorporate this evidence and find meaningful and sound connections between the various concepts. ${ }^{26}$ The second explanation would entail a thorough check of the relationships between our theories and the way in which they are empirically tested. Finally, the last explanation could be tested by building a measure not directly derived from occupation, ${ }^{27}$ also considering that already Hatt (1950) noted that occupation is just one of the many social structures an individual is embedded in. In case the non-occupational measure correlated well with the existing occupation-based ones, then the conclusions concerning the unidimensionality of the latent construct would be confirmed. Otherwise, a new path of research would open for attaining a better understanding of the nature of the available measures of social stratification, and for finding new operational definitions of the hierarchical dimension of social stratification.

\section{Acknowledgements}

The first author wishes to thank Maria Luisa Bianco, head of the former Department of Social Research of the University of Eastern Piedmont at Alessandria (Italy) during the years in which the empirical work reported on in this paper was carried out. The authors also wish to thank the audience of the Social Stratification Research Seminars in Utrecht (2010) and Cambridge (2013), and that of the RC28 Spring Meetings in Haifa (2010), Essex (2011), Hong Kong (2013) and Trento (2014) for helpful comments and suggestions on previous versions of the paper. 


\section{Notes}

1. We intentionally leave social class out of this picture, since we consider a logical priority to examine whether all continuous measures of social stratification index the same latent construct, and only afterwards to consider whether this single construct is empirically distinct from measures of social class.

2. Hall and Caradog Jones (1950) recall that Stevenson built the first occupational classification based on prestige for the 1911 Census in England and Wales; however, it was more a class scheme than an occupational hierarchy as we know it nowadays (I. Upper and middle class; II. Intermediate; III. Skilled workmen; IV. Intermediate; V. Unskilled workmen).

3. See Davis (1927), Anderson (1927, 1934), Wilkinson (1929), Lehman and Witty (1931), Neitz (1935), Hall (1938).

4. Two exceptions to this rule are the study of Lehman and Witty (1931), whose sample of 26,878 students stands out, and of Smith (1943), who asked its respondents to rate a hundred occupations.

5. The list comprises

status, rank, situs, socio-economic status, locum, stratum, station, standing (for naming a generic social position); upper-, middle-, lower-class, parvenu, arrivés, declassés, aristocracy (for specific social positions); prestige-hierarchy, economic-, political-, social-hierarchy (for stratification structures); wealth, power, prestige, achievement, ascription, style of life, status honor, authority (for attributes of positions); the exercising of power, control, influence, exclusion, domination, subordination, discrimination, coercion, manipulation (for the operation of the position). (Merton, 1949/1968, p. 472)

6. Some authors take a rather cautious stance; for example, Hatt agrees that occupation can be an 'index of [social] position ... in spite of its inability to describe in detail the relevant areas of esteem and multistructural position' (1950, p. 534).

7. Actually Weber himself did not draw as sharp boundaries between class and status groups as we may think: 'status may rest on class position of a distinct or ambiguous kind. However, it is not solely determined by it ... Conversely, status may influence, if not completely determine, a class position without being identical with it' (Weber, 1922/1978, p. 306).

8. Some controversy has been raised about the type of data used for building social distance or social status scales, as for whether they come from data concerning friends, or the spouse. In our view, the solution to the controversy comes from going back to Weber's definition of status, which he portrays as entailing restrictions on the pattern of social intercourses as part of the style of life that defines a status group. Weber explicitly mentions two of these patterns, that is, conviviality and connubium, the first referring to the type of persons we eat with, and the second referring to the choice of a partner (Weber 1922/1978, p. 306). As a consequence, it seems that either considering friendship or conjugal association patterns, and as long as these patterns are both governed by status considerations, as Weber suggests, we ought to get the same (or a closely matching) picture.

9. Details of the procedure for the estimation of the scale scores can be found at the following web address: http://www.camsis.stir.ac.uk/overview.html. The original ISSP data files are available from Gesis (www.gesis.org) through the Zacat platform (http://zacat.gesis.org/webview/index.jsp?object= http://zacat.gesis.org/obj/fStudy/ZA3680).

10. For example, furriers and related workers (code 7434) had 3 cases for husbands and 17 for wives, and were joined to textile, leather and related pattern-makers and cutters (code 7435).

11. In our RC-II models, estimated through the software IEM (Vermunt, 1997), row and column scores were constrained to be equal. On a substantive ground, this means that it makes no difference whether it is a man or a woman who holds an occupation.

12. For example, charcoal burners and related workers (code 6142) were not present in the original data set; hence they were given the score of 26.16, which has been estimated for the neighbouring group of forestry workers and loggers (code 6141).

13. The Spss syntax for attributing the ICAMS scores to the ISCO-88 codes is available at the following address: http://www.camsis.stir.ac.uk/versions.html.

14. A third type of validity considered by Zeller and Carmines is content validity, that is, 'the extent to which a set of items taps the content of some domain of interest' $(1980$, p. 78). However, the authors note that 'there is no agreed-upon criteria for establishing whether, in fact, a measure has attained content validity' (1980, p. 79). 
15. Were we to use the same data set on which the scale was built, a good or better performance of the ICAMS against the ISEI and the SIOPS could indeed be due to overfitting to the data used for building it, thus undermining any conclusion.

16. ISCO-88 is the International Standard Classification of Occupations 1988 (ILO, 1990).

17. Actually, the ISEI is estimated on male data, while the SIOPS is built on evaluation of occupational titles; hence only the SIOPS is truly independent from gender, as far as the evaluation of female-segregated occupations does not influence the rater's judgment.

18. Standardisation ensures that all coefficients refer to the same metric and are comparable to one another; within-country standardisation removes potential confounding effects of marginal distributions on coefficients in a pooled analysis (i.e. insofar as these are captured by means and standard deviations).

19. We prefer this measure over the International Standard Level of Education (ISLED), recently developed by Schröder and Ganzeboom (2014) and Schröder (2014), as the ISLED was developed on these same ESS data we use here. Nonetheless, our duration metric is strongly associated with $\operatorname{ISLED}(r=0.94)$.

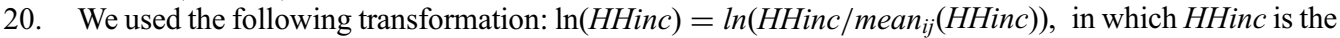
income variable in its original country-specific unit, and mean $_{i j}(H H i n c)$ is its mean for country $i$ and round $j$. Hence $\ln ($ HHinc) measures the log-scale deviation of each income amount from its countryby-round specific mean.

21. The coefficients $c 12$ and $c$.. measure the true score correlation between the two latent occupations and the auxiliary variables; however, they are not under our focus here. We report on a highly constrained version of the model, in which all coefficients of the type $a$ and $b$ are constrained between occupations and all coefficients of the type $d$ and $e$ are constrained between scales. The model as displayed in Figure 1 is not identified all by itself, when restricted to two occupations with two indicators. However, it becomes identified if we include more covariates, either in the form of more occupations or in the form of auxiliary variables. We can then estimate the model either by alternating two indicators for each occupation at a time, or taking all three indicators simultaneously into account. We can also vary the estimation of the model by the subset of occupations involved.

22. In this analysis we complement the educational duration measure with an indicator of educational qualification, as measured by the variable degree in the ISSP 2007 original data file.

23. For reasons we gave elsewhere (see De Luca et al., 2012), we interpret the ICAMS as a status scale, while CAMSIS-like scales are usually interpreted as social distance scales (see for example Bottero \& Prandy, 2003). In light of the results of our previous work, and of those we are going to present in this paper, the sharp distinction between the four conceptual areas we described in Section 2 (social status, prestige, social distance and socio-economic status) loses most of its relevance (see the Conclusion section in this paper).

24. All coefficients come from a model with three simultaneous indicators for the occupations, but the results would not be appreciably different, had the indicators been used on a pairwise basis.

25. We also note that, when two occupations are involved, these attenuations cumulate. For example, in men's case, the correlation between respondent's and spouse's occupation would drop from $0.41 * 0.96 * 0.96=0.38$ in the case of ISEI, to $0.41 * 0.94 * 0.94=0.36$ in the case of ICAMS, to $0.41 * 0.92 * 0.92=0.35$ in that of SIOPS.

26. An attempt in this direction is that of Meraviglia (2012b).

27. As an example, see the scale built by Chapin (1933), cited in Guttman (1942, p. 362).

\section{Notes on contributors}

Cinzia Meraviglia is associate professor at the University of Milan (Italy), where she teaches Social Research Methodology (BA), Inequalities and social mobility (BA), and Research Methods in Social and Political Sciences (PhD). Her research interests are in the field of social stratification, and concern particularly the measuring of social position, the trend over time of inequality of educational opportunity, and the role of mothers in the status and educational attainment processes. She also served as principal investigator of the ISSP in Italy from 2008 to 2011. Recent publications (in English) include 'Class, status and education: The influence of parental resources on IEO in Europe, 1893-1987' (with Maarten L. Buis, International Review of Social Research, 2015).

Harry B.G. Ganzeboom is professor of Sociology and Social Research Methodology at VU University Amsterdam. He is the national coordinator for the ISSP programme in the Netherlands and formerly for the European Social Survey in the Netherlands. His main interest is in the comparative analysis of social stratification and social mobility, as well as the comparative measurement of occupational status and 
educational achievement. Together with Donald J. Treiman, he is the primary author of the International Socio-Economic Index of occupational status [ISEI] and his most often cited work refers to the construction of this index. Recently, together with Heike Schröder, he has proposed the International Standard Level of Education [ISLED] as a parallel instrument for comparative research. Among his other recent contributions is in-depth analysis of Turkish migration to Western Europe, from a country-of-origin perspective.

Deborah De Luca is research fellow at University of Milan, where she collaborates with the courses of Sociology (BA) and Comparative Social Systems (BA). Her main research interests are inequalities in the labour market, social stratification, effects of the recent economic crisis and quantitative methods. Together with Cinzia Meraviglia and Harry B.G. Ganzeboom, she is the author of Measures and dimensions of occupational stratification. The case of a relational scale for Italy, in P. Lambert, R. Connelly, R. Blackburn e V. Gayle (eds), Social stratification: trends and process (Ashgate, 2012).

\section{ORCiD}

Cinzia Meraviglia (D) http://orcid.org/0000-0001-8222-585X

\section{References}

Anderson, W. A. (1927). Occupational attitudes and choices of a group of college men. Social Forces, 2, 467-473.

Anderson, W. A. (1934). The occupational attitudes of college men. Journal of Social Psychology, 5, 435-465.

Blishen, B. R. (1958). The construction and use of an occupational class scale. Canadian Journal of Economics and Political Science, 24, 519-531.

Bottero, W., \& Prandy, K. (2003). Social interaction distance and stratification. British Journal of Sociology, 54, 177-197.

Carmines, E. G., \& Zeller, R. A. (1979). Reliability and validity assessment. Thousand Oaks, CA: SAGE Publications.

Chan, T. W. (Ed.). (2010) Social status and cultural consumption. Cambridge: Cambridge University Press.

Chan, T. W., Birkelund, G. E., Aas, A. K., \& Wiborg, Ø. (2011). Social status in Norway. European Sociological Review, 27, 4, 451-468.

Chan, T. W., \& Goldthorpe, J. H. (2004). Is there a status order in contemporary British society? European Sociological Review, 20, 383-401.

Chan, T. W., \& Goldthorpe, J. H. (2005). The social stratification of theatre, dance and cinema attendance. Cultural Trends, 14, 193-212.

Chan, T. W., \& Goldthorpe, J. H. (2007a). Class and status: The conceptual distinction and its empirical relevance. American Sociological Review, 72, 512-532.

Chan, T. W., \& Goldthorpe, J. H. (2007b). Social status and newspaper readership. American Journal of Sociology, 112, 1095-1134.

Chan, T. W., \& Goldthorpe, J. H. (2007c). Social stratification and cultural consumption: Music in England. European Sociological Review, 23, 1-19.

Chapin, F. S. (1933). The measurement of social status. Minneapolis: University of Minnesota Press.

Clogg, C. C. (1982). Some models for the analysis of association in multiway cross-classifications having ordered categories. Journal of the American Statistical Association, 77, 803-815.

Coleman, J. (1986). Social theory, social research and the theory of action. American Journal of Sociology, 91, 1309-1335.

Counts, G. S. (1925). The social status of occupations. School Review, 33, 16-27.

Coutu, W. (1936). The relative prestige of twenty professions as judged by three groups of professional students. Social Forces, 14, 522-529.

Cronbach, L., \& Meehl, P. (1955). Construct validity in psychological tests. Psychological Bulletin, 52(4), 281-302.

Davis, J. (1927). Testing the social attitudes of children in the government schools in Russia. American Journal of Sociology, 32, 947-952.

De Luca, D., Meraviglia, C., \& Ganzeboom, H. B. G. (2012). Measures and dimensions of occupational stratification: The case of a relational scale for Italy. In P. Lambert, R. Connelly, R. Blackburn, \& V. Gayle (Eds.), Social stratification. Trend and processes (pp. 29-52). Farnham: Ashgate. 
Duncan, O. D. (1961). A socioeconomic index for all occupations. In J. Reiss, Jr. (Ed.), Occupations and social status (pp. 109-138). New York, NY: Free Press of Glencoe.

Featherman, D. L., \& Hauser, R. M. (1976). Prestige or socio-economic scales in the study of occupational achievement? Sociological Methods and Research, 4, 403-422.

Featherman, D. L., Jones, F. L., \& Hauser, R. H. (1975). Assumptions of social mobility research in the US: The case of occupational status. Social Science Research, 4, 329-360.

Ganzeboom, H. B. G. (2014). ESS-DEVO (ESS Developmental Project: Improving the Measurement of Social Background in the European Social Survey). Retrieved from http://www.harryganzeboom.nl/ ESS-DEVO/index.htm

Ganzeboom, H. B. G., De Graaf, P. M., Treiman, D. J., \& De Leeuw, J. (1992). A standard international socio-economic index of occupational status. Social Science Research, 21, 1-56.

Ganzeboom, H. B. G., \& Treiman, D. J. (1989). International stratification and mobility file [machine readable data]. Institute for Social Science Research, UCLA, Los Angeles [distributor].

Ganzeboom, H. B. G., \& Treiman, D. J. (1996). Internationally comparable measures of occupational status for the 1988 ISCO. Social Science Research, 25, 201-239.

Goodman, L. A. (1979). Simple models for the analysis of association in cross-classifications having ordered categories. Journal of the American Statistical Association, 74, 537-552.

Gordon, M. M. (1951). A system of social class analysis. Drew University Bulletin, 39, 3-19.

Griffiths, D., \& Lambert, P. S. (2012). Dimensions and boundaries: Comparative analysis of occupational structures using social network and social interaction distance analysis. Sociological Research Online, 17(2). Retrieved from http://www.socresonline.org.uk/17/2/5.html

Guttman, L. (1942). A revision of Chapin's social status scale. American Sociological Review, 7(3), 362-369.

Hall, C. W. (1938). Social prestige values of a selected group of occupations. Psychological Bulletin, 35, 696-699.

Hall, J., \& Caradog Jones, D. (1950). Social grading of occupations. British Journal of Sociology, 1, 31-55.

Hatt, P. K. (1950). Occupation and social stratification. American Journal of Sociology, 55, 533-543.

Hauser, R. M. (1984). Vertical class mobility in England, France and Sweden. Acta Sociologica, 27(2), 87-110.

Hauser, R. M., \& Logan, J. A. (1992). How not to measure intergenerational occupational persistence. American Journal of Sociology, 97, 1689-1711.

Hollingshead, A. B. (1948). Community research: Development and present condition. American Sociological Review, 13, 136-156.

ILO. (1990). International standard classification of occupations (ISCO-88). Geneva: Author.

Kahl, J. A., \& Davis, J. A. (1955). A comparison of indexes of socio-economic status. American Sociological Review, 24, 395-421.

Kraus, V., Schild, E. O., \& Hodge, R. W. (1978). Occupational prestige in the collective conscience. Social Forces, 56, 900-918.

Lambert, P., \& Bihagen, E. (2012). Stratification research and occupation-based social classifications. In P. Lambert, R. Connelly, R. Blackburn, \& V. Gayln (Eds.), Social stratification. Trend and processes (pp. 13-28). Farnham: Ashgate.

Laumann, E. O. (1965). Subjective social distance in an urban occupational stratification. American Journal of Sociology, 71, 26-36.

Laumann, E. O. (1966). Prestige and association in an urban community. Indianapolis, IN: Bobbs-Merrill.

Laumann, E. O. (1973). Bonds of pluralism. New York: Wiley.

Laumann, E. O., \& Guttman, L. (1966). The relative associational contiguity of occupations in an urban setting. American Sociological Review, 31(2), 169-178.

Lehman, H. C., \& Witty, P. A. (1931). Further study of the social status of occupations. Journal of Educational sociology, 5, 101-112.

MacIver, R., \& Page, C. H. (1949). Society: An introductory analysis. New York, NY: Rinehart.

Meraviglia, C. (Ed.). (2012a). La scala immobile. La stratificazione occupazionale italiana 1985-2005. Bologna: Il Mulino.

Meraviglia, C. (2012b). Una sintesi teorica. In C. Meraviglia (Ed.), La scala immobile. La stratificazione occupazionale italiana 1985-2005 (pp. 49-100). Bologna: Il Mulino.

Merton, R. K. (1949). Social theory and social structure. New York, NY: Free Press.

Neitz, J. A. (1935). The depression and the social status of occupations. The Elementary School Journal, 35 , 454-461.

North, C. C., \& Hatt, P. K. (1947). Jobs and occupations. A popular evaluation. Opinion News, 9, 3-13. 
Parsons, T. (1940). An analytical approach to the theory of sociological stratification. American Journal of Sociology, 45, 841-862.

Pfautz, H. W. (1953). The current literature on social stratification: critique and bibliography. American Journal of Sociology, 58, 391-418.

Prandy, K. (1990). The revised Cambridge scale of occupations. Sociology, 24, 629-655.

Prandy, K., \& Lambert, P. M. (2003). Marriage, social distance and the social space: An alternative derivation and validation of the Cambridge scale. Sociology, 37, 397-411.

Rytina, S. (1992). Scaling the intergenerational continuity of occupation: Is occupational inheritance ascriptive after all? American Journal of Sociology, 97, 1658-1688.

Saris, W. E., \& Andrews, F. M. (1991). Evaluation of measurement instruments using a structural modeling approach. In P. P. Biemer, R. M. Groves, L. E. Lyberg, N. A. Mathiowetz, \& S. Sudman (Eds.), Measurement errors in surveys (pp. 575-597). Hoboken, NJ: Wiley.

Saris, W. E., \& Gallhofer, I. N. (2014). Design, evaluation, and analysis of questionnaires for survey research (2nd ed.). Hoboken, NJ: Wiley Series in Survey Methodology.

Scherpenzeel, A. C., \& Saris, W. E. (1997). The validity and reliability of survey questions: A meta-analysis of MTMM studies. Sociological Methods and Research, 25, 341-383.

Schröder, H. (2014). Levels and loadings: Two methods to improve the measurement of education in comparative research (Unpublished doctoral dissertation). VU University, Amsterdam.

Schröder, H., \& Ganzeboom, H. B. G. (2014). Measuring and modelling level of education in European societies. European Sociological Review, 30(1), 119-136.

Smith, M. (1943). An empirical scale of prestige status of occupations. American Sociological Review, 8, $185-192$.

Stevens, G., \& Featherman, D. L. (1981). A revised socioeconomic index of occupational status. Social Science Research, 10, 364-395.

Stewart, A., Prandy, K., \& Blackburn, R. M. (1973). Measuring the class structure. Nature, 245, 415-417.

Stewart, A., Prandy, K., \& Blackburn, R. M. (1980). Social stratification and occupations. London: Macmillian.

Treiman, D. J. (1977). Occupational prestige in comparative perspective. New York, NY: Academic Press.

Vermunt, J. K. (1997). LEM 1.0: A general program for the analysis of categorical data. Tilburg: Tilburg University.

Warner, W. L., Meeker, M., \& Eells, K. (1949). Social class in America. Chicago, IL: Science Research Associates.

Weber, M. (1922). Wirtschaft und Gesellschaft, Tubingen, Mohr (trans. 1978. Economy and Society: An Outline of Interpretive Sociology). Berkley: University of California Press.

Wheeler, W. (1949). Social stratification in a plains community. Minneapolis, MN: Wayne Wheeler.

Wilkinson, F. (1929). Social distance between occupations. Sociology and Social Research, 13, 234-244.

Williams, R. M. Jr (1951). American society: A sociological interpretation. New York, NY: Knopf.

Zeller, R. A., \& Carmines, E. G. (1980). Measurement in the social sciences. The link between theory and data. Cambridge: Cambridge University Press. 


\section{Appendix}

Table A1. The ICAMS scores for the ISCO-88 occupational titles.

\begin{tabular}{|c|c|c|}
\hline $\begin{array}{l}\text { ISCO- } 88 \\
\text { code }\end{array}$ & ISCO-88 label & $\begin{array}{l}\text { ICAMS } \\
\text { score }\end{array}$ \\
\hline 1000 & $\begin{array}{l}\text { MAJOR GROUP } 1 \text { LEGISLATORS, SENIOR OFFICIALS AND } \\
\text { MANAGERS }\end{array}$ & 65.07 \\
\hline 1100 & LEGISLATORS AND SENIOR OFFICIALS & 69.02 \\
\hline 1110 & LEGISLATORS & \\
\hline 1110 & Legislators & 70.82 \\
\hline 1120 & SENIOR GOVERNMENT OFFICIALS & \\
\hline 1120 & Senior government officials & 70.84 \\
\hline 1130 & TRADITIONAL CHIEFS AND HEADS OF VILLAGES & \\
\hline 1130 & Traditional chiefs and heads of villages & 49.86 \\
\hline 1140 & SENIOR OFFICIALS OF SPECIAL-INTEREST ORGANISATIONS & 64.05 \\
\hline 1141 & Senior officials of political-party organisations & 64.05 \\
\hline 1142 & $\begin{array}{l}\text { Senior officials of employers', workers' and other economic-interest } \\
\text { organisations }\end{array}$ & 64.05 \\
\hline 1143 & Senior officials of humanitarian and other special-interest organisations & 64.05 \\
\hline 1200 & CORPORATE MANAGERS & 67.59 \\
\hline 1210 & DIRECTORS AND CHIEF EXECUTIVES & \\
\hline 1210 & Directors and chief executives & 66.87 \\
\hline 1220 & PRODUCTION AND OPERATIONS DEPARTMENT MANAGERS & 62.86 \\
\hline 1221 & $\begin{array}{l}\text { Production and operations department managers in agriculture, hunting, } \\
\text { forestry and fishing }\end{array}$ & 60.13 \\
\hline 1222 & Production and operations department managers in manufacturing & 60.13 \\
\hline 1223 & Production and operations department managers in construction & 60.13 \\
\hline 1224 & Production and operations department managers in wholesale and retail trade & 58.52 \\
\hline 1225 & Production and operations department managers in restaurants and hotels & 58.52 \\
\hline 1226 & $\begin{array}{l}\text { Production and operations department managers in transport, storage and } \\
\text { communications }\end{array}$ & 58.52 \\
\hline 1227 & Production and operations department managers in business services & 58.52 \\
\hline 1228 & $\begin{array}{l}\text { Production and operations department managers in personal care, cleaning and } \\
\text { related services }\end{array}$ & 60.54 \\
\hline 1229 & Production and operations department managers not elsewhere classified & 60.13 \\
\hline 1230 & OTHER DEPARTMENT MANAGERS & 69.14 \\
\hline 1231 & Finance and administration department managers & 67.11 \\
\hline 1232 & Personnel and industrial relations department managers & 67.11 \\
\hline 1233 & Sales and marketing department managers & 67.11 \\
\hline 1234 & Advertising and public relations department managers & 67.11 \\
\hline 1235 & Supply and distribution department managers & 67.11 \\
\hline 1236 & Computing services department managers & 67.11 \\
\hline 1237 & Research and development department managers & 76.04 \\
\hline 1239 & Other department managers not elsewhere classified & 67.11 \\
\hline 1300 & GENERAL MANAGER & 57.81 \\
\hline 1310 & GENERAL MANAGERS & 57.27 \\
\hline 1311 & General managers in agriculture, hunting, forestry/ and fishing & 41.55 \\
\hline 1312 & General managers in manufacturing & 54.51 \\
\hline 1313 & General managers in construction & 56.18 \\
\hline 1314 & General managers in wholesale and retail trade & 56.18 \\
\hline 1315 & General managers of restaurants and hotels & 56.18 \\
\hline 1316 & General managers in transport, storage and communications & 54.51 \\
\hline 1317 & General managers of business services & 56.18 \\
\hline 1318 & General managers in personal care, cleaning and related services & 54.51 \\
\hline 1319 & General managers not elsewhere classified & 56.18 \\
\hline
\end{tabular}


Table A1. Continued.

\begin{tabular}{|c|c|c|}
\hline $\begin{array}{l}\text { ISCO- } 88 \\
\text { code }\end{array}$ & ISCO-88 label & $\begin{array}{l}\text { ICAMS } \\
\text { score }\end{array}$ \\
\hline 2000 & MAJOR GROUP 2 PROFESSIONALS & 70.89 \\
\hline 2100 & $\begin{array}{l}\text { PHYSICAL, MATHEMATICAL AND ENGINEERING SCIENCE } \\
\text { PROFESSIONALS }\end{array}$ & 75.42 \\
\hline 2110 & PHYSICISTS, CHEMISTS AND RELATED PROFESSIONALS & 81.92 \\
\hline 2111 & Physicists and astronomers & 80.22 \\
\hline 2112 & Meteorologists & 80.22 \\
\hline 2113 & Chemists & 80.22 \\
\hline 2114 & Geologists and geophysicists & 80.22 \\
\hline 2120 & $\begin{array}{l}\text { MATHEMATICIANS, STATISTICIANS AND RELATED } \\
\text { PROFESSIONALS }\end{array}$ & 85.27 \\
\hline 2121 & Mathematicians and related professionals & 85.27 \\
\hline 2122 & Statisticians & 85.27 \\
\hline 2130 & COMPUTING PROFESSIONALS & 75.15 \\
\hline 2131 & Computer systems designers and analysts & 75.39 \\
\hline 2132 & Computer programmers & 72.17 \\
\hline 2139 & Computing professionals not elsewhere classified & 75.39 \\
\hline 2140 & ARCHITECTS, ENGINEERS AND RELATED PROFESSIONALS & 73.00 \\
\hline 2141 & Architects, town and traffic planners & 73.00 \\
\hline 2142 & Civil engineers & 73.00 \\
\hline 2143 & Electrical engineers & 73.00 \\
\hline 2144 & Electronics and telecommunications engineers & 73.00 \\
\hline 2145 & Mechanical engineers & 73.00 \\
\hline 2146 & Chemical engineers & 73.00 \\
\hline 2147 & Mining engineers, metallurgists and related professionals & 73.00 \\
\hline 2148 & Cartographers and surveyors & 73.00 \\
\hline 2149 & Architects, engineers and related professionals not elsewhere classified & 73.00 \\
\hline 2200 & LIFE SCIENCE AND HEALTH PROFESSIONALS & 70.25 \\
\hline 2210 & LIFE SCIENCE PROFESSIONALS & 68.98 \\
\hline 2211 & Biologists, botanists, zoologists and related professionals & 68.98 \\
\hline 2212 & Pharmacologists, pathologists and related professionals & 68.98 \\
\hline 2213 & Agronomists and related professionals & 68.98 \\
\hline 2220 & HEALTH PROFESSIONALS (except nursing) & 78.57 \\
\hline 2221 & Medical doctors & 78.57 \\
\hline 2222 & Dentists & 78.57 \\
\hline 2223 & Veterinarians & 78.57 \\
\hline 2224 & Pharmacists & 78.57 \\
\hline 2229 & Health professionals (except nursing) not elsewhere classified & 78.57 \\
\hline 2230 & NURSING AND MIDWIFERY PROFESSIONALS & 63.21 \\
\hline 2230 & Nursing and midwifery professionals & \\
\hline 2300 & TEACHING PROFESSIONALS & 69.75 \\
\hline 2310 & $\begin{array}{l}\text { COLLEGE, UNIVERSITY AND HIGHER EDUCATION TEACHING } \\
\text { PROFESSIONALS }\end{array}$ & \\
\hline 2310 & College, university and higher education teaching professionals & 82.71 \\
\hline 2320 & SECONDARY EDUCATION TEACHING PROFESSIONALS & \\
\hline 2320 & Secondary education teaching professionals & 71.89 \\
\hline 2330 & $\begin{array}{l}\text { PRIMARY AND PREPRIMARY EDUCATION TEACHING } \\
\text { PROFESSIONALS }\end{array}$ & 63.79 \\
\hline 2331 & Primary education teaching professionals & 63.79 \\
\hline 2332 & Preprimary education teaching professionals & 63.79 \\
\hline 2340 & SPECIAL EDUCATION TEACHING PROFESSIONALS & \\
\hline 2340 & Special education teaching professionals & 73.49 \\
\hline 2350 & OTHER TEACHING PROFESSIONALS & 68.47 \\
\hline 2351 & Education methods specialists & 68.47 \\
\hline
\end{tabular}


Table A1. Continued.

\begin{tabular}{|c|c|c|}
\hline $\begin{array}{l}\text { ISCO- } 88 \\
\text { code }\end{array}$ & ISCO-88 label & $\begin{array}{l}\text { ICAMS } \\
\text { score }\end{array}$ \\
\hline 2352 & School inspectors & 68.47 \\
\hline 2359 & Other teaching professionals not elsewhere classified & 68.47 \\
\hline 2400 & OTHER PROFESSIONALS & 74.02 \\
\hline 2410 & BUSINESS PROFESSIONALS & 68.40 \\
\hline 2411 & Accountants & 68.40 \\
\hline 2412 & Personnel and careers professionals & 68.40 \\
\hline 2419 & Business professionals not elsewhere classified & 68.40 \\
\hline 2420 & LEGAL PROFESSIONALS & 80.43 \\
\hline 2421 & Lawyers & 80.43 \\
\hline 2422 & Judges & 80.43 \\
\hline 2429 & Legal professionals not elsewhere classified & 80.43 \\
\hline 2430 & $\begin{array}{l}\text { ARCHIVISTS, LIBRARIANS AND RELATED INFORMATION } \\
\text { PROFESSIONALS }\end{array}$ & 72.95 \\
\hline 2431 & Archivists and curators & 72.95 \\
\hline 2432 & Librarians and related information professionals & 72.95 \\
\hline 2440 & SOCIAL SCIENCE AND RELATED PROFESSIONALS & 76.83 \\
\hline 2441 & Economists & 76.83 \\
\hline 2442 & Sociologists, anthropologists and related professionals & 76.83 \\
\hline 2443 & Philosophers, historians and political scientists & 76.83 \\
\hline 2444 & Philologists, translators and interpreters & 76.83 \\
\hline 2445 & Psychologists & 76.83 \\
\hline 2446 & Social work professionals & 76.83 \\
\hline 2450 & WRITERS AND CREATIVE OR PERFORMING ARTISTS & 77.15 \\
\hline 2451 & Authors, journalists and other writers & 80.08 \\
\hline 2452 & Sculptors, painters and related artists & 73.32 \\
\hline 2453 & Composers, musicians and singers & 73.32 \\
\hline 2454 & Choreographers and dancers & 73.32 \\
\hline 2455 & Film, stage and related actors and directors & 73.32 \\
\hline 2460 & RELIGIOUS PROFESSIONALS & 73.02 \\
\hline 2460 & Religious professionals & \\
\hline 3000 & $\begin{array}{l}\text { MAJOR GROUP } 3 \text { TECHNICIANS AND ASSOCIATE } \\
\text { PROFESSIONALS }\end{array}$ & 61.26 \\
\hline 3100 & $\begin{array}{l}\text { PHYSICAL AND ENGINEERING SCIENCE ASSOCIATE } \\
\text { PROFESSIONALS }\end{array}$ & 56.68 \\
\hline 3110 & PHYSICAL AND ENGINEERING SCIENCE TECHNICIANS & 54.25 \\
\hline 3111 & Chemical and physical science technicians & 53.17 \\
\hline 3112 & Civil engineering technicians & 53.53 \\
\hline 3113 & Electrical engineering technicians & 53.17 \\
\hline 3114 & Electronics and telecommunications engineering technicians & 53.17 \\
\hline 3115 & Mechanical engineering technicians & 53.53 \\
\hline 3116 & Chemical engineering technicians & 53.17 \\
\hline 3117 & Mining and metallurgical technicians & 53.17 \\
\hline 3118 & Draughtspersons & 53.17 \\
\hline 3119 & Physical and engineering science technicians not elsewhere classified & 53.17 \\
\hline 3120 & COMPUTER ASSOCIATTE PROFESSIONALS & 63.23 \\
\hline 3121 & Computer assistants & 63.01 \\
\hline 3122 & Computer equipment operators & 63.01 \\
\hline 3123 & Industrial robot controllers & 63.01 \\
\hline 3130 & OPTICAL AND ELECTRONIC EQUIPMENT OPERATORS & 61.73 \\
\hline 3131 & Photographers and image and sound recording equipment operators & 61.73 \\
\hline 3132 & Broadcasting and telecommunications equipment operators & 61.73 \\
\hline 3133 & Medical equipment operators & 61.73 \\
\hline
\end{tabular}


Table A1. Continued.

\begin{tabular}{|c|c|c|}
\hline $\begin{array}{l}\text { ISCO- } 88 \\
\text { code }\end{array}$ & ISCO-88 label & $\begin{array}{l}\text { ICAMS } \\
\text { score }\end{array}$ \\
\hline 3139 & Optical and electronic equipment operators not elsewhere classified & 61.73 \\
\hline 3140 & SHIP AND AIRCRAFT CONTROLLERS AND TECHNICIANS & 56.89 \\
\hline 3141 & Ships' engineers & 56.89 \\
\hline 3142 & Ships' deck officers and pilots & 56.89 \\
\hline 3143 & Aircraft pilots and related associate professionals & 56.89 \\
\hline 3144 & Air traffic controllers & 56.89 \\
\hline 3145 & Air traffic safety technicians & 56.89 \\
\hline 3150 & SAFETY AND QUALITY INSPECTORS & 50.50 \\
\hline 3151 & Building and fire inspectors & 50.50 \\
\hline 3152 & Safety, health and quality inspectors & 50.50 \\
\hline 3200 & LIFE SCIENCE AND HEALTH ASSOCIATE PROFESSIONALS & 59.23 \\
\hline 3210 & $\begin{array}{l}\text { LIFE SCIENCE TECHNICIANS AND RELATED ASSOCIATE } \\
\text { PROFESSIONALS }\end{array}$ & 56.58 \\
\hline 3211 & Life science technicians & 56.58 \\
\hline 3212 & Agronomy and forestry technicians & 56.58 \\
\hline 3213 & Farming and forestry advisers & 56.58 \\
\hline 3220 & MODERN HEALTH ASSOCIATE PROFESSIONALS (except nursing) & 68.70 \\
\hline 3221 & Medical assistants & 60.63 \\
\hline 3222 & Sanitarians & 58.95 \\
\hline 3223 & Dieticians and nutritionists & 58.95 \\
\hline 3224 & Optometrists and opticians & 58.95 \\
\hline 3225 & Dental assistants & 58.95 \\
\hline 3226 & Physiotherapists and related associate professionals & 60.63 \\
\hline 3227 & Veterinary assistants & 58.95 \\
\hline 3228 & Pharmaceutical assistants & 58.95 \\
\hline 3229 & $\begin{array}{l}\text { Modern health associate professionals (except nursing) not elsewhere } \\
\text { classified }\end{array}$ & 60.63 \\
\hline 3230 & NURSING AND MIDWIFERY ASSOCIATE PROFESSIONALS & 58.79 \\
\hline 3231 & Nursing associate professionals & 58.79 \\
\hline 3232 & Midwifery associate professionals & 58.79 \\
\hline 3240 & TRADITIONAL MEDICINE PRACTITIONERS AND FAITH HEALERS & 48.10 \\
\hline 3241 & Traditional medicine practitioners & 48.10 \\
\hline 3242 & Faith healers & 48.10 \\
\hline 3300 & TEACHING ASSOCIATE PROFESSIONALS & 62.76 \\
\hline 3310 & PRIMARY EDUCATION TEACHING ASSOCIATE PROFESSIONALS & \\
\hline 3310 & Primary education teaching associate professionals & 66.16 \\
\hline 3320 & $\begin{array}{l}\text { PREPRIMARY EDUCATION TEACHING ASSOCIATE } \\
\text { PROFESSIONALS }\end{array}$ & \\
\hline 3320 & Preprimary education teaching associate professionals & 57.73 \\
\hline 3330 & SPECIAL EDUCATION TEACHING ASSOCIATE PROFESSIONALS & \\
\hline 3330 & Special education teaching associate professionals & 66.05 \\
\hline 3340 & OTHER TEACHING ASSOCIATE PROFESSIONALS & \\
\hline 3340 & Other teaching associate professionals & 64.70 \\
\hline 3400 & OTHER ASSOCIATE PROFESSIONALS & 60.89 \\
\hline 3410 & FINANCE AND SALES ASSOCIATE PROFESSIONALS & 60.99 \\
\hline 3411 & Securities and finance dealers and brokers & 59.95 \\
\hline 3412 & Insurance representatives & 59.95 \\
\hline 3413 & Estate agents & 59.95 \\
\hline 3414 & Travel consultants and organisers & 59.95 \\
\hline 3415 & Technical and commercial sales representatives & 59.95 \\
\hline 3416 & Buyers & 54.30 \\
\hline 3417 & Appraisers, valuers and auctioneers & 59.95 \\
\hline 3419 & Finance and sales associate professionals not elsewhere classified & 54.30 \\
\hline
\end{tabular}


Table A1. Continued.

\begin{tabular}{|c|c|c|}
\hline $\begin{array}{l}\text { ISCO- } 88 \\
\text { code }\end{array}$ & ISCO-88 label & $\begin{array}{l}\text { ICAMS } \\
\text { score }\end{array}$ \\
\hline 3420 & BUSINESS SERVICES AGENTS AND TRADE BROKERS & 60.84 \\
\hline 3421 & Trade brokers & 60.84 \\
\hline 3422 & Clearing and forwarding agents & 60.84 \\
\hline 3423 & Employment agents and labour contractors & 60.84 \\
\hline 3429 & Business services agents and trade brokers not elsewhere classified & 60.84 \\
\hline 3430 & ADMINISTRATIVE ASSOCIATE PROFESSIONALS & 59.99 \\
\hline 3431 & Administrative secretaries and related associate professionals & 58.22 \\
\hline 3432 & Legal and related business associate professionals & 60.33 \\
\hline 3433 & Bookkeepers & 58.22 \\
\hline 3434 & Statistical, mathematical and related associate professionals & 60.33 \\
\hline 3439 & Administrative associate professionals not elsewhere classified & 58.22 \\
\hline 3440 & $\begin{array}{l}\text { CUSTOMS, TAX AND RELATED GOVERNMENT ASSOCIATE } \\
\text { PROFESSIONALS }\end{array}$ & 61.24 \\
\hline 3441 & Customs and architect border inspectors & 57.79 \\
\hline 3442 & Government tax and excise officials & 57.79 \\
\hline 3443 & Government social benefits officials & 57.79 \\
\hline 3444 & Government licensing officials & 57.79 \\
\hline 3449 & $\begin{array}{l}\text { Customs, tax and related government associate professionals not elsewhere } \\
\text { classified }\end{array}$ & 55.23 \\
\hline 3450 & POLICE INSPECTORS AND DETECTIVES & \\
\hline 3450 & Police inspectors and detectives & 53.56 \\
\hline 3460 & SOCIAL WORK ASSOCIATE PROFESSIONALS & \\
\hline 3460 & Social work associate professionals & 61.32 \\
\hline 3470 & $\begin{array}{l}\text { ARTISTIC, ENTERTAINMENT AND SPORTS ASSOCIATE } \\
\text { PROFESSIONALS }\end{array}$ & 63.04 \\
\hline 3471 & Decorators and commercial designers & 67.45 \\
\hline 3472 & Radio, television and other announcers & 61.96 \\
\hline 3473 & Street, night-club and related musicians, singers and dancers & 61.96 \\
\hline 3474 & Clowns, magicians, acrobats and related associate professionals & 61.96 \\
\hline 3475 & Athletes, sportspersons and related associate professionals & 61.96 \\
\hline 3480 & RELIGIOUS ASSOCIATE PROFESSIONALS & \\
\hline 3480 & Religious associate professionals & 64.85 \\
\hline 4000 & MAJOR GROUP 4 CLERKS & $\mathbf{5 5 . 5 4}$ \\
\hline 4100 & OFFICE CLERKS & 55.33 \\
\hline 4110 & SECRETARIES AND KEYBOARD-OPERATING CLERKS & 59.26 \\
\hline 4111 & Stenographers and typists & 59.26 \\
\hline 4112 & Word-processor and related operators & 59.26 \\
\hline 4113 & Data entry operators & 59.26 \\
\hline 4114 & Calculating-machine operators & 59.26 \\
\hline 4115 & Secretaries & 59.26 \\
\hline 4120 & NUMERICAL CLERKS & 56.87 \\
\hline 4121 & Accounting and bookkeeping clerks & 55.80 \\
\hline 4122 & Statistical and finance clerks & 55.80 \\
\hline 4130 & MATERIAL-RECORDING AND TRANSPORT CLERKS & 44.97 \\
\hline 4131 & Stock clerks & 44.97 \\
\hline 4132 & Production clerks & 44.97 \\
\hline 4133 & Transport clerks & 44.97 \\
\hline 4140 & LIBRARY, MAIL AND RELATED CLERKS & 48.77 \\
\hline 4141 & Library and filing clerks & 48.77 \\
\hline 4142 & Mail carriers and sorting clerks & 48.77 \\
\hline 4143 & Coding, proof-reading and related clerks & 48.77 \\
\hline 4144 & Scribes and related workers & 48.77 \\
\hline 4190 & OTHER OFFICE CLERKS & \\
\hline
\end{tabular}


Table A1. Continued.

\begin{tabular}{|c|c|c|}
\hline $\begin{array}{l}\text { ISCO-88 } \\
\text { code }\end{array}$ & ISCO-88 label & $\begin{array}{l}\text { ICAMS } \\
\text { score }\end{array}$ \\
\hline 4190 & Other office clerks & 56.27 \\
\hline 4200 & CUSTOMER SERVICES CLERKS & 52.33 \\
\hline 4210 & CASHIERS, TELLERS AND RELATED CLERKS & 50.16 \\
\hline 4211 & Cashiers and ticket clerks & 50.16 \\
\hline 4212 & Tellers and other counter clerks & 50.16 \\
\hline 4213 & Bookmakers and croupiers & 50.16 \\
\hline 4214 & Pawnbrokers and money-lenders & 50.16 \\
\hline 4215 & Debt-collectors and related workers & 50.16 \\
\hline 4220 & CLIENT INFORMATION CLERKS & 54.96 \\
\hline 4221 & Travel agency and related clerks & 54.96 \\
\hline 4222 & Receptionists and information clerks & 54.96 \\
\hline 4223 & Telephone switchboard operators & 54.96 \\
\hline 5000 & $\begin{array}{l}\text { MAJOR GROUP } 5 \text { SERVICE WORKERS AND SHOP AND MARKET } \\
\text { SALES WORKERS }\end{array}$ & 43.65 \\
\hline 5100 & PERSONAL AND PROTECTIVE SERVICES WORKERS & 43.44 \\
\hline 5110 & TRAVEL ATTENDANTS AND RELATED WORKERS & 51.45 \\
\hline 5111 & Travel attendants and travel stewards & 51.45 \\
\hline 5112 & Transport conductors & 51.45 \\
\hline 5113 & Travel guides & 51.45 \\
\hline 5120 & HOUSEKEEPING AND RESTAURANT SERVICES WORKERS & 38.29 \\
\hline 5121 & Housekeepers and related workers & 38.29 \\
\hline 5122 & Cooks & 38.29 \\
\hline 5123 & Waiters, waitresses and bartenders & 38.29 \\
\hline 5130 & PERSONAL CARE AND RELATED WORKERS & 45.77 \\
\hline 5131 & Child-care workers & 45.77 \\
\hline 5132 & Institution-based personal care workers & 45.77 \\
\hline 5133 & Home-based personal care workers & 45.77 \\
\hline 5139 & Personal care and related workers not elsewhere classified & 45.77 \\
\hline 5140 & OTHER PERSONAL SERVICES WORKERS & 46.24 \\
\hline 5141 & Hairdressers, barbers, beauticians and related workers & 46.16 \\
\hline 5142 & Companions and valets & 25.51 \\
\hline 5143 & Undertakers and embalmers & 43.35 \\
\hline 5149 & Other personal services workers not elsewhere classified & 43.35 \\
\hline 5150 & ASTROLOGERS, FORTUNE-TELLERS AND RELATED WORKERS & 33.43 \\
\hline 5151 & Astrologers and related workers & 33.43 \\
\hline 5152 & Fortune-tellers, palmists and related workers & 33.43 \\
\hline 5160 & PROTECTIVE SERVICES WORKERS & 45.99 \\
\hline 5161 & Fire-fighters & 44.73 \\
\hline 5162 & Police officers & 44.73 \\
\hline 5163 & Prison guards & 44.73 \\
\hline 5169 & Protective services workers not elsewhere classified & 44.73 \\
\hline 5200 & MODELS, SALESPERSONS AND DEMONSTRATORS & 44.41 \\
\hline 5210 & FASHION AND OTHER MODELS & \\
\hline 5210 & Fashion and other models & 49.36 \\
\hline 5220 & SHOP SALESPERSONS AND DEMONSTRATORS & \\
\hline 5220 & Shop salespersons and demonstrators & 45.26 \\
\hline 5230 & STALL AND MARKET SALESPERSONS & \\
\hline 5230 & Stall and market salespersons & 35.48 \\
\hline 6000 & $\begin{array}{l}\text { MAJOR GROUP } 6 \text { SKILLED AGRICULTURAL AND FISHERY } \\
\text { WORKERS }\end{array}$ & 36.49 \\
\hline 6100 & $\begin{array}{l}\text { MARKET-ORIENTED SKILLED AGRICULTURAL AND FISHERY } \\
\text { WORKERS }\end{array}$ & 38.31 \\
\hline 6110 & MARKET GARDENERS AND CROP GROWERS & 38.20 \\
\hline
\end{tabular}


Table A1. Continued.

\begin{tabular}{|c|c|c|}
\hline $\begin{array}{l}\text { ISCO- } 88 \\
\text { code }\end{array}$ & ISCO-88 label & $\begin{array}{l}\text { ICAMS } \\
\text { score }\end{array}$ \\
\hline 6111 & Field crop and vegetable growers & 32.13 \\
\hline 6112 & Tree and shrub crop growers & 36.35 \\
\hline 6113 & Gardeners, horticultural and nursery growers & 36.35 \\
\hline 6114 & Mixed-crop growers & 33.15 \\
\hline 6120 & $\begin{array}{l}\text { MARKET-ORIENTED ANIMAL PRODUCERS AND RELATED } \\
\text { WORKERS }\end{array}$ & 42.35 \\
\hline 6121 & Dairy and livestock producers & 42.17 \\
\hline 6122 & Poultry producers & 42.17 \\
\hline 6123 & Apiarists and sericulturists & 42.17 \\
\hline 6124 & Mixed-animal producers & 42.17 \\
\hline 6129 & $\begin{array}{l}\text { Market-oriented animal producers and related workers not elsewhere } \\
\text { classified }\end{array}$ & 42.17 \\
\hline 6130 & MARKET-ORIENTED CROP AND ANIMAL PRODUCERS & \\
\hline 6130 & Market-oriented crop and animal producers & 41.55 \\
\hline 6140 & FORESTRY AND RELATED WORKERS & 30.08 \\
\hline 6141 & Forestry workers and loggers & 26.19 \\
\hline 6142 & Charcoal burners and related workers & 26.19 \\
\hline 6150 & FISHERY WORKERS, HUNTERS AND TRAPPERS & 21.98 \\
\hline 6151 & Aquatic-life cultivation workers & 33.33 \\
\hline 6152 & Inland and coastal waters fishery/ workers & 19.64 \\
\hline 6153 & Deep-sea fishery workers & 19.64 \\
\hline 6154 & Hunters and trappers & 19.64 \\
\hline 6200 & SUBSISTENCE AGRICULTURAL AND FISHERY WORKERS & 13.19 \\
\hline 6210 & SUBSISTENCE AGRICULTURAL AND FISHERY WORKERS & \\
\hline 6210 & Subsistence agricultural and fishery/ workers & 13.19 \\
\hline 7000 & MAJOR GROUP 7 CRAFT AND RELATED TRADES WORKERS & 34.89 \\
\hline 7100 & EXTRACTION AND BUILDING TRADES WORKERS & 32.92 \\
\hline 7110 & MINERS, SHOTFIRERS, STONE CUTTERS AND CARVERS & 29.42 \\
\hline 7111 & Miners and quarry workers & 26.39 \\
\hline 7112 & Shotfirers and blasters & 26.39 \\
\hline 7113 & Stone splitters, cutters and carvers & 26.39 \\
\hline 7120 & BUILDING FRAME AND RELATED TRADES WORKERS & 31.41 \\
\hline 7121 & Builders, traditional materials & 30.68 \\
\hline 7122 & Bricklayers and stonemasons & 30.68 \\
\hline 7123 & Concrete placers, concrete finishers and related workers & 26.14 \\
\hline 7124 & Carpenters and joiners & 30.68 \\
\hline 7129 & Building frame and related trades workers not elsewhere classified & 30.68 \\
\hline 7130 & BUILDING FINISHERS AND RELATED TRADES WORKERS & 39.00 \\
\hline 7131 & Roofers & 39.00 \\
\hline 7132 & Floor layers and tile setters & 39.00 \\
\hline 7133 & Plasterers & 39.00 \\
\hline 7134 & Insulation workers & 39.00 \\
\hline 7135 & Glaziers & 39.00 \\
\hline 7136 & Plumbers and pipe fitters & 39.00 \\
\hline 7137 & Building and related electricians & 39.00 \\
\hline 7140 & $\begin{array}{l}\text { PAINTERS, BUILDING STRUCTURE CLEANERS AND RELATED } \\
\text { TRADES WORKERS }\end{array}$ & 32.95 \\
\hline 7141 & Painters and related workers & 32.24 \\
\hline 7142 & Varnishers and related painters & 32.94 \\
\hline 7143 & Building structure cleaners & 32.94 \\
\hline 7200 & METAL, MACHINERY AND RELATED TRADES WORKERS & 37.97 \\
\hline
\end{tabular}


Table A1. Continued.

\begin{tabular}{|c|c|c|}
\hline $\begin{array}{l}\text { ISCO-88 } \\
\text { code }\end{array}$ & ISCO-88 label & $\begin{array}{l}\text { ICAMS } \\
\text { score }\end{array}$ \\
\hline 7210 & $\begin{array}{l}\text { METAL MOULDERS, WELDERS, SHEET-METAL WORKERS, } \\
\text { STRUCTURAL- METAL PREPARERS, AND RELATED TRADES } \\
\text { WORKERS }\end{array}$ & 33.30 \\
\hline 7211 & Metal moulders and coremakers & 33.30 \\
\hline 7212 & Welders and flamecutters & 33.30 \\
\hline 7213 & Sheet metal workers & 33.30 \\
\hline 7214 & Structural-metal preparers and erectors & 33.30 \\
\hline 7215 & Riggers and cable splicers & 33.30 \\
\hline 7216 & Underwater workers & 35.65 \\
\hline 7220 & BLACKSMITHS, TOOL-MAKERS AND RELATED TRADES WORKERS & 35.65 \\
\hline 7221 & Blacksmiths, hammer-smiths and forging-press workers & 35.65 \\
\hline 7222 & Tool-makers and related workers & 35.65 \\
\hline 7223 & Machine-tool setters and setter-operators & 35.65 \\
\hline 7224 & Metal wheel-grinders, polishers and tool sharpeners & 35.65 \\
\hline 7230 & MACHINERY MECHANICS AND FITTERS & 39.82 \\
\hline 7231 & Motor vehicle mechanics and fitters & 39.43 \\
\hline 7232 & Aircraft engine mechanics and fitters & 50.81 \\
\hline 7233 & Agricultural- or industrial-machinery mechanics and fitters & 35.44 \\
\hline 7240 & $\begin{array}{l}\text { ELECTRICAL AND ELECTRONIC EQUIPMENT MECHANICS AND } \\
\text { FITTERS }\end{array}$ & 43.57 \\
\hline 7241 & Electrical mechanics and fitters & 42.58 \\
\hline 7242 & Electronics fitters & 42.58 \\
\hline 7243 & Electronics mechanics and servicers & 46.59 \\
\hline 7244 & Telegraph and telephone installers and servicers & 42.58 \\
\hline 7245 & Electrical line installers, repairers and cable jointers & 42.58 \\
\hline 7300 & $\begin{array}{l}\text { PRECISION, HANDICRAFT, PRINTING AND RELATED TRADES } \\
\text { WORKERS }\end{array}$ & 43.86 \\
\hline 7310 & PRECISION WORKERS IN METAL AND RELATED MATERIALS & 46.82 \\
\hline 7311 & Precision-instrument makers and repairers & 45.98 \\
\hline 7312 & Musical instrument makers and tuners & 45.98 \\
\hline 7313 & Jewellery and precious-metal workers & 45.98 \\
\hline 7320 & POTTERS, GLASS-MAKERS AND RELATED TRADES WORKERS & 32.12 \\
\hline 7321 & Abrasive wheel formers, potters and related workers & 32.12 \\
\hline 7322 & Glass makers, cutters, grinders and finishers & 32.12 \\
\hline 7323 & Glass engravers and etchers & 32.12 \\
\hline 7324 & Glass, ceramics and related decorative painters & 32.12 \\
\hline 7330 & $\begin{array}{l}\text { HANDICRAFT WORKERS IN WOOD,TEXTILE, LEATHER AND } \\
\text { RELATED MATERIALS }\end{array}$ & 39.72 \\
\hline 7331 & Handicraft workers in wood and related materials & 38.27 \\
\hline 7332 & Handicraft workers in textile, leather and related materials & 38.27 \\
\hline 7340 & PRINTING AND RELATED TRADES WORKERS & 47.39 \\
\hline 7341 & Compositors, typesetters and related workers & 47.39 \\
\hline 7342 & Stereotypers and electrotypers & 47.39 \\
\hline 7343 & Printing engravers and etchers & 47.39 \\
\hline 7344 & Photographic and related workers & 47.39 \\
\hline 7345 & Bookbinders and related workers & 47.39 \\
\hline 7346 & Silk-screen, block and textile printers & 47.39 \\
\hline 7400 & OTHER CRAFT AND RELATED TRADES WORKERS & 32.57 \\
\hline 7410 & FOOD PROCESSING AND RELATED TRADES WORKERS & 31.22 \\
\hline 7411 & Butchers, fishmongers and related food preparers & 28.43 \\
\hline 7412 & Bakers, pastry-cooks and confectionery makers & 31.36 \\
\hline 7413 & Dairy-products makers & 31.36 \\
\hline 7414 & Fruit, vegetable and related preservers & 28.43 \\
\hline
\end{tabular}


Table A1. Continued.

\begin{tabular}{|c|c|c|}
\hline $\begin{array}{l}\text { ISCO-88 } \\
\text { code }\end{array}$ & ISCO-88 label & $\begin{array}{l}\text { ICAMS } \\
\text { score }\end{array}$ \\
\hline 7415 & Food and beverage tasters and graders & 28.43 \\
\hline 7416 & Tobacco preparers and tobacco products makers & 28.43 \\
\hline 7420 & $\begin{array}{l}\text { WOOD TREATERS, CABINET-MAKERS AND RELATED TRADES } \\
\text { WORKERS }\end{array}$ & 34.59 \\
\hline 7421 & Wood treaters & 28.25 \\
\hline 7422 & Cabinet makers and related workers & 35.48 \\
\hline 7423 & Woodworking machine setters and setter-operators & 28.25 \\
\hline 7424 & Basketry weavers, brush makers and related workers & 34.59 \\
\hline 7430 & TEXTILE, GARMENT AND RELATED TRADES WORKERS & 34.28 \\
\hline 7431 & Fibre preparers & 31.58 \\
\hline 7432 & Weavers, knitters and related workers & 31.58 \\
\hline 7433 & Tailors, dressmakers and hatters & 31.58 \\
\hline 7434 & Furriers and related workers & 34.44 \\
\hline 7435 & Textile, leather and related pattern-makers and cutters & 34.44 \\
\hline 7436 & Sewers, embroiderers and related workers & 31.58 \\
\hline 7437 & Upholsterers and related workers & 31.58 \\
\hline 7440 & PELT, LEATHER AND SHOEMAKING TRADES WORKERS & 25.96 \\
\hline 7441 & Pelt dressers, tanners and fellmongers & 22.20 \\
\hline 7442 & Shoe-makers and related workers and related workers & 25.30 \\
\hline 8000 & $\begin{array}{l}\text { MAJOR GROUP } 8 \text { PLANT AND MACHINE OPERATORS AND } \\
\text { ASSEMBLERS }\end{array}$ & 32.80 \\
\hline 8100 & STATIONARY-PLANT AND RELATED OPERATORS & 33.31 \\
\hline 8110 & MINING- AND MINERAL-PROCESSING PLANT OPERATORS & 36.94 \\
\hline 8111 & Mining-plant operators & 32.92 \\
\hline 8112 & Mineral-ore- and stone-processing-plan operators & 36.75 \\
\hline 8113 & Well drillers and borers and related workers & 36.75 \\
\hline 8120 & METAL-PROCESSING-PLANT OPERATORS & 27.00 \\
\hline 8121 & Ore and metal furnace operators & 27.00 \\
\hline 8122 & Metal melters, casters and rolling-mill operators & 27.00 \\
\hline 8123 & Metal-heat-treating-plant operators & 27.00 \\
\hline 8124 & Metal drawers and extruders & 27.00 \\
\hline 8130 & GLASS, CERAMICS AND RELATED PLANT OPERATORS & 25.76 \\
\hline 8131 & Glass and ceramics kiln and related machine operators & 25.76 \\
\hline 8139 & Glass, ceramics and related plant operators not elsewhere classified & 25.76 \\
\hline 8140 & WOOD-PROCESSING- AND PAPERMAKING-PLANT OPERATORS & 31.66 \\
\hline 8141 & Wood-processing-plant operators & 31.66 \\
\hline 8142 & Paper-pulp plant operators & 31.66 \\
\hline 8143 & Papermaking-plant operators & 31.66 \\
\hline 8150 & CHEMICAL-PROCESSING-PLANT OPERATORS & 37.27 \\
\hline 8151 & Crushing-, grinding- and chemical-mixing machinery operators & 37.27 \\
\hline 8152 & Chemical-heat-treating-plant operators & 37.27 \\
\hline 8153 & Chemical-filtering- and separating-equipment operators & 37.27 \\
\hline 8154 & Chemical-still and reactor operators (except petroleum and natural gas) & 37.27 \\
\hline 8155 & Petroleum- and natural-gas-refining-plant operators & 37.27 \\
\hline 8159 & Chemical-processing-plant operators not elsewhere classified & 37.27 \\
\hline 8160 & POWER-PRODUCTION AND RELATED PLANT OPERATORS & 36.70 \\
\hline 8161 & Power-production plant operators & 37.80 \\
\hline 8162 & Steam-engine and boiler operators & 32.97 \\
\hline 8163 & Incinerator, water-treatment and related plant operators & 32.97 \\
\hline 8170 & $\begin{array}{l}\text { AUTOMATED-ASSEMBLY-LINE AND INDUSTRIAL-ROBOT } \\
\text { OPERATORS }\end{array}$ & 37.92 \\
\hline 8171 & Automated-assembly-line operators & 37.92 \\
\hline 8172 & Industrial-robot operators & 37.92 \\
\hline
\end{tabular}


Table A1. Continued.

\begin{tabular}{|c|c|c|}
\hline $\begin{array}{l}\text { ISCO- } 88 \\
\text { code }\end{array}$ & ISCO-88 label & $\begin{array}{l}\text { ICAMS } \\
\text { score }\end{array}$ \\
\hline 8200 & MACHINE OPERATORS AND ASSEMBLERS & 32.71 \\
\hline 8210 & METAL- AND MINERAL-PRODUCTS MACHINE OPERATORS & 30.77 \\
\hline 8211 & Machine-tool operators & 30.77 \\
\hline 8212 & Cement and other mineral products machine operators & 30.77 \\
\hline 8220 & CHEMICAL-PRODUCTS MACHINE OPERATORS & 33.41 \\
\hline 8221 & Pharmaceutical- and toiletry-products machine operators & 28.95 \\
\hline 8222 & Ammunition- and explosive-products machine operators & 33.41 \\
\hline 8223 & Metal finishing-, plating- and coating-machine operators & 28.95 \\
\hline 8224 & Photographic-products machine operators & 45.26 \\
\hline 8229 & Chemical-products machine operators not elsewhere classified & 28.95 \\
\hline 8230 & RUBBER-AND PLASTIC-PRODUCTS MACHINE OPERATORS & 28.18 \\
\hline 8231 & Rubber-products machine operators & 28.18 \\
\hline 8232 & Plastic-products machine operators & 28.18 \\
\hline 8240 & WOOD-PRODUCTS MACHINE OPERATORS & 26.09 \\
\hline 8240 & Wood-products machine operators & \\
\hline 8250 & $\begin{array}{l}\text { PRINTING-, BINDING- AND PAPER-PRODUCTS MACHINE } \\
\text { OPERATORS }\end{array}$ & 40.54 \\
\hline 8251 & Printing-machine operators & 40.88 \\
\hline 8252 & Bookbinding-machine operators & 40.88 \\
\hline 8253 & Paper-products machine operators & 40.88 \\
\hline 8260 & TEXTILE-, FUR- AND LEATHER-PRODUCTS MACHINE OPERATORS & 30.00 \\
\hline 8261 & Fibre-preparing-, spinning- and winding machine operators & 24.65 \\
\hline 8262 & Weaving- and knitting-machine operators & 24.65 \\
\hline 8263 & Sewing machine operators & 29.14 \\
\hline 8264 & Bleaching-, dyeing- and cleaning-machine operators & 29.14 \\
\hline 8265 & Fur and leather-preparing-machine operators & 24.65 \\
\hline 8266 & Shoemaking- and related machine operators & 24.65 \\
\hline 8269 & Textile-, fur- and leather-products machine operators not elsewhere classified & 24.65 \\
\hline 8270 & FOOD AND RELATED PRODUCTS MACHINE OPERATORS & 28.38 \\
\hline 8271 & Meat- and fish-processing-machine operators & 28.34 \\
\hline 8272 & Dairy-products machine operators & 28.34 \\
\hline 8273 & Grain- and spice-milling-machine operators & 28.34 \\
\hline 8274 & Baked-goods, cereal and chocolate-products machine operators & 28.34 \\
\hline 8275 & Fruit-, vegetable- and nut-processing-machine operators & 28.34 \\
\hline 8276 & Sugar production machine operators & 28.34 \\
\hline 8277 & Tea-, coffee-, and cocoa-processing-machine operators & 28.34 \\
\hline 8278 & Brewers-, wine and other beverage machine operators & 28.34 \\
\hline 8279 & Tobacco production machine operators & 28.34 \\
\hline 8280 & ASSEMBLERS & 37.52 \\
\hline 8281 & Mechanical-machinery assemblers & 37.52 \\
\hline 8282 & Electrical-equipment assemblers & 37.52 \\
\hline 8283 & Electronic-equipment assemblers & 37.52 \\
\hline 8284 & Metal-, rubber- and plastic-products assemblers & 37.52 \\
\hline 8285 & Wood and related products assemblers & 37.52 \\
\hline 8286 & Paperboard, textile and related products assemblers & 37.52 \\
\hline 8290 & OTHER MACHINE OPERATORS AND ASSEMBLERS & 34.52 \\
\hline 8290 & Other machine operators and assemblers & 34.52 \\
\hline 8300 & DRIVERS AND MOBILE-PLANT OPERATORS & 34.75 \\
\hline 8310 & LOCOMOTIVE-ENGINE DRIVERS AND RELATED WORKERS & 37.45 \\
\hline 8311 & Locomotive-engine drivers & 37.45 \\
\hline 8312 & Railway brakers, signallers and shunters & 37.45 \\
\hline 8320 & MOTOR-VEHICLE DRIVERS & 36.43 \\
\hline 8321 & Motor-cycle drivers & 24.76 \\
\hline
\end{tabular}


Table A1. Continued.

\begin{tabular}{|c|c|c|}
\hline $\begin{array}{l}\text { ISCO- } 88 \\
\text { code }\end{array}$ & ISCO-88 label & $\begin{array}{l}\text { ICAMS } \\
\text { score }\end{array}$ \\
\hline 8322 & Car, taxi and van drivers & 35.67 \\
\hline 8323 & Bus and tram drivers & 35.67 \\
\hline 8324 & Heavy truck and lorry drivers & 35.67 \\
\hline 8330 & AGRICULTURAL AND OTHER MOBILE-PLANT OPERATORS & 31.86 \\
\hline 8331 & Motorised farm and forestry plant operators & 31.86 \\
\hline 8332 & Earth-moving and related plant operators & 31.86 \\
\hline 8333 & Crane, hoist and related plant operators & 31.86 \\
\hline 8334 & Lifting-truck operators & 31.86 \\
\hline 8340 & SHIPS' DECK CREWS AND RELATED WORKERS & 43.00 \\
\hline 8340 & Ships' deck crews and related workers & \\
\hline 9000 & MAJOR GROUP 9 ELEMENTARY OCCUPATIONS & 27.85 \\
\hline 9100 & SALES AND SERVICES ELEMENTARY OCCUPATIONS & 28.70 \\
\hline 9110 & STREET VENDORS AND RELATED WORKERS & 33.37 \\
\hline 9111 & Street food vendors & 35.05 \\
\hline 9112 & Street vendors, non-food products & 30.41 \\
\hline 9113 & Door-to-door and telephone salespersons & 35.05 \\
\hline 9120 & $\begin{array}{l}\text { SHOE CLEANING AND OTHER STREET SERVICES ELEMENTARY } \\
\text { OCCUPATIONS }\end{array}$ & \\
\hline 9120 & Shoe cleaning and other street services elementary occupations & 25.69 \\
\hline 9130 & $\begin{array}{l}\text { DOMESTIC AND RELATED HELPERS, CLEANERS AND } \\
\text { LAUNDERERS }\end{array}$ & 26.71 \\
\hline 9131 & Domestic helpers and cleaners & 25.01 \\
\hline 9132 & Helpers and cleaners in offices, hotels and other establishments & 25.01 \\
\hline 9133 & Hand-launderers and pressers & 24.69 \\
\hline 9140 & BUILDING CARETAKERS, WINDOW AND RELATED CLEANERS & 35.41 \\
\hline 9141 & Building caretakers & 35.42 \\
\hline 9142 & Vehicle, window and related cleaners & 29.68 \\
\hline 9150 & $\begin{array}{l}\text { MESSENGERS, PORTERS, DOORKEEPERS AND RELATED } \\
\text { WORKERS }\end{array}$ & 33.34 \\
\hline 9151 & Messengers, package and luggage porters and deliverers & 33.34 \\
\hline 9152 & Doorkeepers, watchpersons and related workers & 33.34 \\
\hline 9153 & Vending-machine money collectors, meter readers and related workers & 33.34 \\
\hline 9160 & GARBAGE COLLECTORS AND RELATED LABOURERS & 21.07 \\
\hline 9161 & Garbage collectors & 21.07 \\
\hline 9162 & Sweepers and related labourers & 21.07 \\
\hline 9200 & AGRICULTURAL, FISHERY AND RELATED LABOURERS & 22.45 \\
\hline 9210 & AGRICULTURAL, FISHERY AND RELATED LABOURERS & 23.43 \\
\hline 9211 & Farm-hands and labourers & 23.43 \\
\hline 9212 & Forestry labourers & 23.43 \\
\hline 9213 & Fishery, hunting and trapping labourers & 23.43 \\
\hline 9300 & $\begin{array}{l}\text { LABOURERS IN MINING, CONSTRUCTION, MANUFACTURING AND } \\
\text { TRANSPORT }\end{array}$ & 28.16 \\
\hline 9310 & MINING AND CONSTRUCTION LABOURERS & 26.18 \\
\hline 9311 & Mining and quarrying labourers & 26.12 \\
\hline 9312 & $\begin{array}{l}\text { Construction and maintenance labourers: roads, dams and similar } \\
\text { constructions }\end{array}$ & 26.12 \\
\hline 9313 & Building construction labourers & 24.99 \\
\hline 9320 & MANUFACTURING LABOURERS & 30.71 \\
\hline 9321 & Assembling labourers & 30.71 \\
\hline 9322 & Hand packers and other manufacturing labourers & 30.71 \\
\hline 9330 & TRANSPORT LABOURERS AND FREIGHT HANDLERS & 31.24 \\
\hline 9331 & Hand or pedal vehicle drivers & 23.60 \\
\hline 9332 & Drivers of animal-drawn vehicles and machinery & 23.60 \\
\hline 9333 & Freight handlers & 29.48 \\
\hline
\end{tabular}


Table A2. Latent correlations between the latent variables with one another, and with the auxiliary variables (generic MTMM model, women and men).

\begin{tabular}{|c|c|c|c|c|c|c|c|c|c|c|}
\hline & & \multicolumn{4}{|c|}{ Occupation } & \multicolumn{4}{|c|}{ Education } & \multirow{2}{*}{$\begin{array}{c}\text { Householc } \\
\text { income }\end{array}$} \\
\hline & & Father & Mother & Respondent & Spouse & Father & Mother & Respondent & Spouse & \\
\hline \multicolumn{11}{|l|}{ (a) Women } \\
\hline \multirow{3}{*}{ Occupation } & Father & $\begin{array}{c}1 \\
0486\end{array}$ & & & & & & & & \\
\hline & Mother & $\begin{array}{l}0.486 \\
0.314\end{array}$ & $\begin{array}{c}1 \\
0.329\end{array}$ & 1 & & & & & & \\
\hline & Respondent & $\begin{array}{l}0.314 \\
0.274\end{array}$ & 0.268 & 0.447 & 1 & & & & & \\
\hline \multirow{4}{*}{ Education } & Father & 0.545 & 0.444 & 0.335 & 0.291 & 1 & & & & \\
\hline & Mother & 0.414 & 0.565 & 0.322 & 0.266 & 0.657 & 1 & & & \\
\hline & Respondent & 0.353 & 0.372 & 0.644 & 0.430 & 0.432 & 0.423 & 1 & & \\
\hline & Spouse & 0.285 & 0.279 & 0.429 & 0.611 & 0.400 & 0.367 & 0.524 & 1 & \\
\hline \multicolumn{2}{|c|}{ Household income } & 0.162 & 0.165 & 0.341 & 0.361 & 0.173 & 0.170 & 0.312 & 0.313 & 1 \\
\hline \multicolumn{11}{|l|}{ (b) Men } \\
\hline \multirow[t]{4}{*}{ Occupation } & Father & 1 & & & & & & & & \\
\hline & Mother & 0.483 & 1 & & & & & & & \\
\hline & Respondent & 0.318 & 0.296 & 1 & & & & & & \\
\hline & Spouse & 0.269 & 0.283 & 0.447 & 1 & & & & & \\
\hline \multirow[t]{4}{*}{ Education } & Father & 0.547 & 0.444 & 0.323 & 0.299 & 1 & & & & \\
\hline & Mother & 0.417 & 0.564 & 0.279 & 0.280 & 0.655 & 1 & & & \\
\hline & Respondent & 0.351 & 0.336 & 0.623 & 0.457 & 0.420 & 0.375 & 1 & & \\
\hline & Spouse & 0.282 & 0.293 & 0.408 & 0.619 & 0.399 & 0.393 & 0.532 & 1 & \\
\hline \multicolumn{2}{|c|}{ Household income } & 0.173 & 0.163 & 0.364 & 0.360 & 0.183 & 0.160 & 0.330 & 0.330 & 1 \\
\hline
\end{tabular}

